Law \& Economics Working Papers

Law \& Economics Working Papers Archive:

2003-2009

\title{
Private Regulation of Insider Trading in The Shadow of Lax Public Enforcement (and a Strong Neighbor): Evidence from Canadian Firms
}

\author{
Anita I. Anand* \\ Laura N. Beny ${ }^{\dagger}$
}

*University of Toronto Faculty of Law, anita.anand@utoronto.ca

${ }^{\dagger}$ University of Michigan Law School, lbeny@umich.edu

This paper is posted at University of Michigan Law School Scholarship Repository.

http://repository.law.umich.edu/law_econ_archive/art77 


\title{
Private Regulation of Insider Trading in The Shadow of Lax Public Enforcement (and a Strong Neighbor): Evidence from Canadian Firms
}

\author{
Anita I. Anand and Laura N. Beny * \\ (C) 2007 Laura N. Beny and Anita I. Anand. All rights reserved.
}

November 2007

\footnotetext{
* The authors are from the Faculty of Law, University of Toronto (anita.anand@utoronto.ca) and the University of Michigan Law School (lbeny@umich.edu), respectively. They are grateful to Michael Barr, Anusha Chari, Richard Epstein, Peter Henry, Howell Jackson, Jessica Litman, Randall Morck, Adam Pritchard, Darren Roulstone, and Christopher Thomas for insightful comments and suggestions, and to Michael Bond, Rohan Brown, Laura Kawano, William Lumsden, Kevin Mak, and Robert Sommers for excellent research assistance and $\mathrm{Al}$ LaGrone for excellent editorial assistance. The authors also thank the participants in the 2007 Annual Conference on Empirical Legal Studies, the University of Toronto Law and Economics Discussion Group, the 2007 Annual Conference of the American Law and Economics Association, the 2006 Annual Conference of the Canadian Law and Economics Association and the Faculty at Chicago Kent for helpful comments and suggestions. Professor Beny gratefully acknowledges financial support from the Cook Fund at the University of Michigan Law School and the IPC Post-Crisis Global Financial Flows Project of the Ford School of Public Policy, University of Michigan. The authors are especially grateful to Richard Lempert for extensive comments and guidance.
} 


\section{Introduction}

Despite legal prohibitions on trading by corporate insiders who have material undisclosed information, many U.S. and Canadian firms also have private insider trading policies (ITPs) that restrict trading by their executives and other employees. In many cases, these ITPs are more stringent than the host country's insider trading laws. Although insider trading laws are the subject of several recent comparative empirical studies (see, e.g., Beny, 2005, 2007a, 2007b, 2008; Bhattacharya and Daouk, 2002; Bris, 2005; Bushman et al., 2005; Maug and Ackerman, 2006; Durnev and Nain, 2007; Korczak and Lasfer, 2006; Fernandes and Ferreira, 2007), very few studies examine firms' voluntary regulation of insider trading through ITPs (see, e.g. Bettis et al, 2000; Roulstone, 2003). Bettis et al. (2000) find that voluntary insider trading policies are widespread in the United States. Ninety-two percent of their sample firms have an ITP and 78\% of these firms have an ITP that is more stringent than U.S. insider trading laws. Similarly, as we demonstrate in this article, a significant proportion of publicly-traded Canadian firms have private ITPs. These, too, are frequently more restrictive than Canadian insider trading laws.

ITPs are interesting in part because they implicate an influential empirical claim in the law and economics literature on insider trading, namely that shareholders seldom, if ever, negotiated corporate contracts banning insider trading when it was legal (Carlton and Fischel, 1983). Some scholars argue that the absence of such contracts proves that shareholders did not object to insider trading and thus the prohibition of insider trading is unnecessary and even efficiency reducing (Carlton and Fischel, 1983). ${ }^{1}$ One may wonder why firms voluntarily adopt

\footnotetext{
1 Some American legal scholars argue that the fact that there were few private contracts prohibiting insider trading in the United States prior to the legal prohibition suggests that firms and shareholders had no desire to restrict insider trading (Carlton and Fischel 1983). From this, they conclude that insider trading is not inefficient. These scholars implicitly dismiss the possibility that shareholders lacked the capacity to negotiate such contracts because of information deficiencies, asymmetric bargaining power, and insider self-dealing (Cox 1986; Easterbrook
} 
ITPs when insider trading is already illegal, and especially if firms did not privately restrict insider trading when it was legal.

There are at least four explanations for why firms establish ITPs. The first and most obvious explanation is that firms may adopt ITPs to demonstrate legal compliance and thus avoid corporate liability, since having an ITP in place may shield a corporation from insider trading liability (Jagolinzer and Roulstone, 2007; Bettis et al., 2000), as we explain below. This explanation resolves the apparent inconsistency between the claim that firms did not desire to restrict insider trading when it was legal and the fact that many firms privately restrict insider trading now that it is illegal. Specifically, firms would not adopt an ITP but for the prohibition of insider trading. Second, firms may adopt ITPs to reduce trading costs and thus increase the liquidity of their shares, since evidence suggests that insider trading increases trading costs (Bhattacharya and Daouk, 2002; Beny, 2005; Copeland and Galai, 1983; Glosten and Harris, 1988). Third, firms may adopt ITPs to reduce agency costs, i.e., the costs that arise from the divergence of interests between managers and shareholders and the consequent need for shareholders to monitor managers (Jensen and Meckling, 1976). Several proponents of insider trading restrictions argue that insider trading distorts managers' and dominant shareholders incentives to the detriment of corporate value small outside shareholders (see., e.g, Kraakman, 1991; Maug, 2002). The first explanation, the compliance/liability avoidance rationale, does not necessarily imply that firms perceive insider trading per se to be economically harmful. In contrast, the second and third explanations suggest that firms privately restrict insider trading to enhance economic efficiency and thus challenge the twin claims that firms do not dislike insider

1985). Thus, they ignore the possibility that the absence of a ban made stock markets and firms less efficient than they otherwise might have been. In addition, contractual restrictions would probably be unenforceable absent regulatory intervention. Computerized surveillance is required to detect insider trading and public (or quasi-public) regulators have access to such technology, while corporations generally are not in the business of trade surveillance, let alone self-reporting of insider trading violations. 
trading and would not restrict it but for the law. These explanations are not mutually exclusive, and a firm may adopt an ITP for one or more of the foregoing reasons.

Alternatively, ITPs may be mere "window dressing", if they are costless for firms to enact and publicize. Under the window dressing rationale, firms adopt toothless ITPs solely to curry favor with outside investors, who may misguidedly view insider trading as unfair or immoral. The work of Bettis et al. (2000) suggests that ITPs are effective, however. Bettis and his co-authors find that even in the U.S., where insider trading laws are vigorously enforced, ITPs suppress insider trading. ${ }^{2}$ They find that bid-ask spreads are lower, i.e., liquidity is higher, during black-out periods, i.e., periods in which insiders are forbidden to trade pursuant to an ITP. Their results suggest that U.S. firms adopt ITPs at least partly for economic reasons. Bettis and his co-authors take ITPs as given, however, and do not investigate whether some firms are more inclined to adopt ITPs or more stringent ITPs than other firms. Roulstone (2003) does investigate firm-level determinants of private restrictions on insider trading and finds that larger firms and firms with greater analyst following (publicity), greater institutional ownership, and past experience of a lawsuit for insider trading are more likely to adopt private insider trading restrictions. Like Bettis et al. (2000), though, Roulstone does not exploit variation in ITP stringency across firms.

In this pilot study, we take the next steps and investigate firm-level determinants of both ITP existence and ITP stringency. Investigating why firms differ in their proclivity to adopt both ITPs and ITPs of varying stringency will, we hope, illuminate firms' motives for adopting ITPs and thus inform the insider trading debate. We develop five testable hypotheses based on the assumption that firms that face greater costs from insider trading (or greater benefits from

2 Indeed, Bettis et al. (2000) suggest that ITPs and public enforcement may be more effective at suppressing insider trading than public enforcement alone. 
restricting insider trading) will be more inclined than other firms to adopt ITPs and ITPs that are more restrictive than existing insider trading law. As explained in greater detail below, we hypothesize that ITPs and ITP stringency are positively associated with: (1) firm size, (2) a firm's market-to-book ratio, (3) concentrated share ownership/control, (4) firm-specific stock return volatility, and (5) cross-listing on a U.S. stock exchange.

We investigate our hypotheses using a sample of 181 firms that were included in the Toronto Stock Exchange/Standard \& Poor's (TSX/S\&P) Index as of December 31, 2005. The TSX is Canada's largest stock exchange, accounting for over $80 \%$ of Canada's equity trading volume between 1987 and 2000 (McNally and Smith, 2003). For each firm in our sample, we examine whether the firm has an ITP and the substance of the firm's ITP, if one exists, including whether it is more stringent than Canadian insider trading law. We use firm-specific characteristics to test our predictions about the kinds of firms that are likely to establish ITPs and, for the adopting group, the relative strictness of the firm's ITP. We are able to test our hypotheses because not all TSX-listed firms have an ITP and, among those that do have such a policy, these policies vary in their degree of stringency relative to Canadian insider trading law.

The Canadian stock market is a useful context in which to test our hypotheses for several reasons. First, as we elaborate in greater detail below, insider trading enforcement is relatively lax in Canada. If firms view insider trading as economically harmful, this ought to give Canadian firms an incentive to adopt ITPs, and possibly ITPs that are more stringent than Canadian insider trading law. Conversely, if firms view insider trading as economically beneficial, lax enforcement ought to create an incentive for Canadian firms to forego ITPs or confine them to what the law requires. Second, Canadian firms tend to have more concentrated share ownership, and thus a greater prevalence of controlling shareholders (who are often 
insiders), than U.S. firms (Daniels and Iacobucci, 1999; Daniels and Morck, 1995). Controlling shareholders are more able to engage in insider trading than other shareholders because of their ready access to private information (Maug 2002; Bhide 1993; Demsetz 1986). Lax enforcement and a greater prevalence of controlling shareholders suggests that insider trading may be relatively prevalent in Canada. Finally, since insider trading laws are more vigorously enforced in the U.S. than in Canada, Canadian firms cross-listed in the U.S. may adopt ITPs to avoid insider trading liability in the U.S. Cross-listed Canadian firms may also view having an ITP as gratuitous advertising in Canada of conditions that they have a strong incentive to adhere to in the U.S., which would support the window dressing rationale in Canada and the compliance/liability avoidance rationale in the U.S.

We find that most of the firms in our sample (80\%) have an ITP and just less than half (44\%) of these firms have an ITP that is more restrictive than Canadian insider trading law. Thus, voluntary ITPs are common among firms on the TSX/S\&P Index. In addition, our results corroborate four of our five hypotheses, a striking outcome in light of our relatively small sample size. First, the larger is the firm, the greater the likelihood it has an ITP and the more stringent its ITP is likely to be. Second, the more controlling shareholders a firm has, the more likely it is to have both an ITP and an ITP that is stricter than Canadian insider trading law. Third, firms with greater firm-specific stock return volatility are more apt to have both ITPs and more stringent ITPs than firms with lower firm-specific return volatility. Fourth, firms cross-listed on a U.S. stock exchange are more likely than those not cross-listed on a U.S. stock exchange to have an ITP and one more stringent than what Canadian law requires. Our data fail to support only one of our five hypotheses, the market-to-book hypothesis. 
Our results suggest that neither window dressing, legal compliance/liability avoidance, nor U.S. regulatory imperialism fully explains Canadian firms' adoption of ITPs. TSX/S\&P firms display a range of private approaches to insider trading that roughly correlate, we argue, with the private costs and benefits of restricting insider trading. Thus, our findings suggest that at least some firms wish to control insider trading for economic, i.e., efficiency reasons. Importantly, our results also suggest that some shareholders, and influential ones at that, oppose insider trading. Furthermore, our results suggest that formal organizational rules may dominate private sanctions in producing our results, which corroborates a normative theory of organizational rules as opposed to an economic deterrence theory. On balance, our findings support, even if they do not prove, the claim that firms perceive insider trading to be inimical to their interests.

The remainder of the article fills out these points. Part 2 discusses the motivation for this study and briefly reviews relevant literature. Part 3 describes Canadian law and recommended best practices on insider trading and highlights the more important differences between the Canadian and U.S. insider trading regimes. Part 4 presents in more detail our hypotheses regarding the kinds of firms that are likely to have an ITP or an ITP that is stricter than Canadian insider trading law. Part 5 describes our data and empirical methodology and presents the results. Finally, Part 6 concludes.

\section{Motivation and Literature Review}

Even though insider trading is generally illegal (Bhattacharya and Daouk 2002), the debate among legal and financial scholars about whether insider trading ought to be regulated has persisted since the 1960s. What is at stake in the debate is the appropriate allocation of 
rights to benefit from corporate information (Macey 1991). ${ }^{3}$ The question legal scholars pose is whether such rights ought to be available equally to the firm/outside shareholders or whether corporate insiders ought to benefit exclusively from their privileged access to such information. The fact that insider trading is illegal, at least on the books, in virtually every country with a stock market suggests that lawmakers around the world, unlike some scholars, believe the better policy is to make rights to trade on corporate information more equally available. ${ }^{4}$

In the early years, the debate centered on whether insider trading is unfair to public investors not privy to private corporate information (Schotland 1967; see also Brudney 1979). In the late 1960s, the terms of the debate shifted from the fairness of insider trading to its economic efficiency when Professor Manne published his influential book, Insider Trading and the Stock Market, in which he argued that insider trading is efficient and hence desirable. He justified his conclusion by arguing that the ability to engage in insider trading motivates insiders to be more entrepreneurial and leads to more accurate stock prices, i.e., stock prices that reflect all current information about a stock's "true" value and not merely public information (Manne 1966).

As the debate on the efficiency of insider trading continued, a third position emerged. This intermediate position maintains that insider trading is efficient for some firms and inefficient for others (Epstein 2004; Haddock and Macey 1987). Proponents of the intermediate position believe that corporate efficiency would be maximized if regulators allowed firms, shareholders and corporate insiders to contract privately over whether to allow or prohibit insider trading within a firm. The market, they maintain, will ensure that the appropriate bargain will be

3 Macey (1991) likens this right to a property right in corporate information. However, it is not exactly a property right because insiders cannot summon the law to protect corporate information from others, even when trading on inside information is legal. Likewise, outsiders cannot use the law to monopolize such information. Arrow's (1962) characterization of business information as a public good is a more apt description, though like many other public goods some parties are in a far better position to exploit it. See Beny (2007b) for a political economy analysis of insider trading legislation and enforcement.

$4 \quad$ Lawmakers have rejected full equality of access, however, probably because of the infeasibility and probable inefficiency of full equality. See, e.g., Chiarella v. United States, 445 U.S. 222 (1980). 
struck for each firm, prohibiting insider trading by contract in cases where it is inefficient and allowing insider trading where it is efficient (Haddock and Macey 1987; Carlton and Fischel 1983).

This theoretical debate resists resolution because, as noted above, we live in a world where insider trading is illegal in virtually every stock market. Thus, in a departure from the pure Coasian theme, ITPs are adopted in the shadow of insider trading laws. This means that ITPs are skewed toward greater strictness than existing law because if they are less strict, they add nothing to the law's rigor and may even create legal liability. Thus, U.S. and Canadian ITPs are left-censored, i.e., they are either equally or more restrictive, and are never more permissive, than what the respective insider trading laws require. Still, ITPs are somewhat like contractual choices to prohibit insider trading, except that companies seem to adopt them unilaterally and they do not spring from direct negotiations between insiders and outside shareholders. We aim to understand the firm-level determinants of these quasi-contractual choices in relation to Canadian insider trading law and thereby inform the perennial theoretical debate.

This article contributes to the recent wave of comparative empirical research on insider trading regulation, by focusing on the Canadian stock market, which is heavily influenced by economic and regulatory events in U.S. This recent scholarship attempts to understand the economic (efficiency) consequences of insider trading laws by exploiting statistical variation in such laws across countries. ${ }^{5}$ Thus far, the evidence seems to support the regulatory stance rather than the deregulatory position. Beny $(2007 \mathrm{a}, 2005)$ reports that more stringent insider trading laws are associated with more dispersed equity ownership, more accurate stock prices, and greater stock market liquidity. Bhattacharya and Daouk (2002), using data from all countries

$5 \quad$ Although it is not possible to compare markets without regulation to markets with regulation, since insider trading is illegal in almost every stock market, it is possible to compare markets with varying degrees of regulation and enforcement. This is what the recent literature does. 
with stock markets, find that stock market liquidity systematically increased after insider trading regulation was enacted and the cost of equity fell significantly after the first incidence of enforcement. Bushman et al. (2005) find that investment analyst attention, which is widely thought to be beneficial to stock market efficiency, increases after a country enforces its insider trading laws. Beny (2008) finds that insider trading laws are associated with greater corporate valuation among firms with a controlling shareholder in common law countries. Finally, Bris (2005) finds that insider trading profits prior to tender offer announcements decrease with the stringency of insider trading laws (as coded by Beny 2005).

Our research also contributes to the recent empirical literature on voluntary corporate governance. The bulk of this literature investigates whether firm performance is affected by voluntary governance practices (Coles et al, 2000; Doidge, Karolyi and Stultz, 2003; Black, Jang and Kim, 2005). There is relatively less focus on which factors predict a firm's adoption of governance standards. Durnev and Kim (2005), however, examine this issue. They find that investment opportunities, external financing, and ownership structure significantly influence voluntary governance practices and that the strength of their influence depends in part on a country's legal environment. In addition, Anand, Milne and Purda (2006) find that many Canadian firms voluntarily adopt governance practices over and above those required by Canadian corporate legislation and the number of Canadian firms voluntarily adopting such practices is increasing. Anand and her co-authors also find that it is not only the home country's governance regime that influences the stringency of the governance practices adopted but also the corporate governance standards of the United States, where many Canadian firms seek external finance. Since ITPs are essentially voluntary corporate governance standards, this article contributes to this literature as well as to the comparative literature on insider trading. By 
exploring the characteristics that lead Canadian firms to adopt ITPs, we illuminate how firm characteristics affect an important subset of corporate governance rules.

\section{A Comparison between the Canadian and U.S. Insider Trading Regimes}

Canada does not have a national securities regulator (Wise Person's Committee, 2003).

Thus, securities laws, including insider trading laws, are enacted and enforced at the provincial level, unlike in the U.S. where securities laws are federally enacted and enforced. In this section, we focus on the insider trading law of the province of Ontario, which is home to both the Toronto Stock Exchange, where our sample firms are listed, and Canada's largest capital markets. $^{6}$

In Ontario, the basic rules on insider trading are set forth in statutes that define both legal and illegal insider trading. ${ }^{7}$ Insiders (a defined class) may trade, provided that their trades are not based on undisclosed (non-public) material information and are reported within ten days from the date of the trade. The relevant legal provision states, "No person or company in a special relationship with a reporting issuer shall purchase or sell securities of the reporting issuer with the knowledge of a material fact or material change with respect to the reporting issuer that has not been generally disclosed". The precise legal elements of illegal insider trading in Ontario are thus: a) a special relationship between the insider and the issuing corporation; b) material information; and c) undisclosed information. Tipping, defined as informing any other person of undisclosed material information other than in the necessary course of business, is also

$6 \quad$ We do not present the insider trading laws of all of Canada's thirteen jurisdictions, since Ontario insider trading law applies to our sample firms and, at any rate, insider trading laws across Canada are generally harmonized and therefore similar, if not identical, to Ontario insider trading law.

$7 \quad$ Section 107 and section 76, Securities Act (Ontario), R.S.O 1990. 
prohibited under the statute. ${ }^{8}$ Appendix 1 contains a description of the statutory provisions relating to insider trading in the province of Ontario.

While Canadian firms are not legally required to adopt an ITP, it is a recommended best practice for them to do so. National Policy 51-101, "Disclosure Standards", contains best practices relating to disclosure, and recommends that firms: appoint a senior officer to approve and monitor trading by all insiders, prohibit insiders and employees from trading while in possession of material non-public information, specify blackout periods (explicit periods during which all trading is prohibited) that apply to insiders, officers and employees, ${ }^{9}$ and establish procedures by which insiders, officers and employees must apply for approval to trade during blackout periods. While not a recommended best practice per se, firms may also adopt internal (i.e., private) enforcement or disciplinary mechanisms in their ITPs consisting of such measures as unpaid leave, suspension or even dismissal for those who violate the rules.

In addition to the foregoing recommended best practice, National Policy 58-201 sets forth various corporate governance guidelines (as opposed to mandatory rules), including a recommendation that boards adopt a "code of business conduct and ethics." ${ }^{10}$ As we note below, some Canadian firms choose to implement an ITP as part of this code. Although Canadian firms are not required to adopt such a code, once a firm adopts one, it must file the

$8 \quad$ Section 76(1)-(5), Securities Act (Ontario).

A blackout period, for example, may extend from one month before the firm's earnings release - the period in which the firm is preparing its financial statements, management discussion and analysis (MD\&A) and other material, non-public information - to two days after the firm publicly issues its earnings release - to give the market time to disseminate and incorporate the new information into the firm's share price (see, e.g., Jagolinzer and Roulstone, 2007; Roulstone, 2003; Bettis et al., 2000). ITPs may also contain a brownout period, a period during which some but not all insiders are restricted from trading. For example, an ITP may bar the persons who are part of a "deal team" working on a significant transaction involving the firm from trading until the deal is publicly disclosed.

10 National Instrument 58-201 “Corporate Governance Practices” online http://www.osc.gov.on.ca/Regulation/Rulemaking/Current/Part5/rule_20041029 58-201_corp-gov-guidelines.jsp.. 
code and disclosure regarding the code's contents is mandatory. ${ }^{11}$ However, particulars of the ITP may not be included in such disclosure. Most importantly, the choice whether to adopt an ITP is ultimately voluntary in Canada. None of the post-Sarbanes Oxley corporate governance legislation implemented in Canada requires firms to adopt an ITP. ${ }^{12}$ In addition, relative to other optional corporate governance standards, Canadian securities regulators have not pressed firms to adopt these policies. ${ }^{13}$

U.S. insider trading laws differ from Canadian insider trading laws in several respects. First, as noted above, Canadian provincial securities statutes explicitly forbid insiders from purchasing or selling securities based on material information which has not been publicly disclosed. By contrast, in the U.S., Rule 10b-5 of the Securities Exchange Act of 1934 is a general anti-fraud provision that prohibits the use of "any device, scheme, or artifice" or any "act, practice or course of business" to defraud or deceive "in connection with the purchase or sale of any security" (17 C.F.R. $\S 240.10 b-5)$. On its face, Rule 10b-5, which we reproduce in Appendix 1, does not prohibit insider trading. Since the 1960s, however, U.S. courts have consistently interpreted the rule as prohibiting corporate insiders from trading on the basis of material, nonpublic information unless they publicly disclose such information prior to trading. ${ }^{14}$

$11 \quad$ National Instrument 58-101 - Disclosure of Corporate Governance Practices and Form 58-101F1Corporate Governance Disclosure, (2005) 28 OSCB 5377. The voluntary nature of the Canadian regime suggests that our results may understate the prevalence of voluntary ITPs among Canadian firms, to the extent that some firms that have such policies have chosen not to report them. We will address this issue in a subsequent study by directly asking firms whether they have an ITP and for its contents, if they have one. In this article, we will rely on publicly reported information.

12 In 2004, subsequent to the Sarbanes-Oxley reforms in the U.S., Canadian securities regulators adopted mandatory corporate governance rules requiring certification of financial statements and audit committee composition. Multilateral Instrument 52-109- Certification of Disclosure in Issuers' Annual and Interim Filing (2004) 27 OSCB 3230 as amended in (2005) 28 OSCB 4979; Multilateral Instrument 52-110 - Audit Committees (2004) 27 OSCB 3252 as amended in (2005) 28 OSCB 5387.

13 In a few cases, however, the Ontario Securities Commission (OSC) required the firm to adopt an ITP in a legal settlement of insider trading claims against the firm. See, e.g., In the Matter of Zoran Popovic and Dxstorm.com Inc. (2005).

14 This is the so-called "disclose or abstain" rule. A seminal early case was SEC v. Texas Gulf Sulphur Co., 401 F.2d 833 (2d Cir. 1968), cert. denied, 394 U.S. 976 (1969). U.S. federal case law treats insider trading as a 
Effectively, then, the basic Canadian and U.S. insider trading prohibitions are the same, even though the U.S. prohibition does not explicitly address insider trading as such. In both countries, insiders may trade their firms' securities if such trading is not based on material undisclosed information. In addition, in both countries, insiders must disclose changes in the ownership of their positions, including all purchases and dispositions of the firm's securities.

Second, short-swing profits are permissible in Canada but prohibited in the U.S. In the U.S., Section 16(b) of the Securities Exchange Act of 1934 requires an insider who buys (sells) the securities of the issuer and sells (buys) them within six months to give the resulting profits to the company (17 C.F.R. $\S 240.16$ (b), reproduced in Appendix 1). ${ }^{15}$ Section 16(b), unlike Rule 10b-5, covers only directors, officers, or stockholders owning more than $10 \%$ of the firm's shares. In addition, as a prophylactic rule, Section 16(b) applies regardless of whether an insider trades on immaterial or public information, arguably over-deterring trading by corporate insiders. ${ }^{16}$ In contrast, Canada does not prohibit short-swing profits. Moreover, foreign firms (including Canadian firms) that are cross-listed in the U.S. are exempt from Section 16(b).

Third, U.S. and Canadian insider trading laws differ in how they define an "insider". In Canada, the insider trading prohibition applies to individuals who are in a "special relationship" with the firm. The statutory definition of special relationship in Canadian law is broad and includes a number of persons who would not fall under the U.S.'s formal definition of violation of common law fiduciary duties. See, e.g., Chiarella v. United States, 445 U.S. 222 (1980) and Dirks v. SEC, 463 U.S. 646 (1983).

15 It is straightforward to see how an insider might profit from buying and then selling her company's shares within a six-month period. A profit will result if she buys the shares at a lower price than the price at which she subsequently sells them. It is less obvious how she might profit from selling and then buying her company's shares within a six month period. A "profit" will result, however, in the form of "loss avoidance," if she sells the shares at a higher price than the price at which she subsequently buys them back. For example, if the insider sells the shares on January 1 for $\$ 20$ and then buys them back on March 1 for $\$ 5$, she will have avoided a loss of \$15. Another way in which she might profit from a sell-buy transaction is by selling the shares short (i.e., borrowing the shares and then selling them) at the current market price which is higher than the price at which she subsequently will buy them back in order to return the shares to the lender and close the contract. Insiders are prohibited from short-selling in the U.S. under Section 16(b), but not in Canada (Anita: please confirm this).

16 For a critique of Section 16(b) from a Canadian perspective, see Davies (1975). 
"insider". ${ }^{17}$ In the U.S., Section 16(a)(1) of the Securities and Exchange Act of 1934 indirectly defines insiders as officers, directors and $10 \%$ shareholders. ${ }^{18}$ Although this definition is not as broad as its Canadian statutory counterpart, U.S. case law articulates a broad range of additional individuals who are subject to the basic insider trading prohibition. For example, tippees are prohibited from trading in the U.S., even though they are neither insiders nor in any special relationship with the firm (see, e.g., Dirks v. SEC, 463 U.S. 646 (1983)). In addition, U.S. case law extends the insider trading prohibition to so-called "constructive" or "secondary" insiders, a class that includes the firm's lawyers, investment bankers, accountants, and others in possession of confidential corporate information (see, e.g., Dirks v. SEC, 463 U.S. 646 (1983); SEC v. Lund, 623 F.2d 796 (2d Cir. 1980)). Finally, the misappropriation theory, an American judicial doctrine, extends the insider trading prohibition to persons who do not have a fiduciary duty to the firm or its shareholders, but who have a fiduciary duty to the source of the information (see, e.g., United States v. O'Hagan, 521 U.S. 642 (1997)). Thus, there is little effective difference between Canada and the U.S. concerning the scope of the basic insider trading prohibition.

Finally, unlike in Canada, it is not a recommended best practice for U.S. firms to adopt ITPs. Nevertheless, U.S. law provides a strong incentive for firms to adopt private codes governing insider trading because under Section 20A of the Securities and Exchange Act of 1934 (“The Insider Trading and Securities Fraud Enforcement Act of 1988”) a firm may be held derivatively liable for its employees' illegal insider trading unless the firm can prove that it acted in good faith and did not induce such trading. One way a firm can provide evidence of good

17 Insiders include not only people in a special relationship with the firm but also parties making a takeover bid or engaged in some other proposed transaction with the issuer. Directors, officers and employees are considered insiders, as are individuals who learned of a material fact or change from any of these individuals. Insiders include any person who learns of a material fact or change from anyone described in the statutory definition and who should have known that the person from whom she received such information was in a special relationship with the issuer. (Anita: can you add citation to statutory provision?)

18 Moreover, Rule 16a-1(f) defines "officer". 
faith and non-inducement is to show that it had an ITP in place prior to the alleged illegal trading and that the employees traded in spite of the internal prohibition (e.g., a blackout period), as in the ImClone case.

The most important distinction between the U.S. and Canadian insider trading regimes by far is enforcement. The U.S. has both a longer history and greater intensity of insider trading enforcement than Canada. The Ontario Securities Commission (OSC) conducted its first insider trading prosecution in 1973, while the first U.S. insider trading case occurred more than a decade earlier. Since then, there have been few insider trading convictions and no successful tipping convictions $^{19}$ in Canada (McNally and Smith, 2003). According to McNally and Smith (2003), “[o]n average, there has been less than one insider trading conviction a year since 1980 [and] only two cases where insiders were charged with failure to report their trading activity." By comparison, over the same period the U.S. Securities and Exchange Commission (SEC) settled or prosecuted over 550 insider trading cases (McNally and Smith, 2003). Two reasons for the difficulty of obtaining insider trading convictions in Canada (especially in cases brought in provincial court) are the relatively high burden of proving scienter (Davies, 1975; Canadian Insider Trading Task Force, 2003) and apparent ambiguities in interpreting the applicable materiality standard. ${ }^{20}$ Another reason is Canada's relatively thin budget for insider trading enforcement (Wise Person's Committee, 2003).

The U.S. and Canadian comparative insider trading enforcement patterns are consistent with their general comparative securities enforcement experiences (Wise Person's Committee, 2003; Jackson, 2006). Jackson (2006) compares U.S. and Canadian enforcement budgets and

19 R. v. Rankin, [2006] O.J. No. 4579 (Sup. Ct. Just., Nordheimer J., 9 November 2006), overturning [2005] O.J. No. 3202 (Ont. Ct. Just., Khawly J.). Anita: can you elaborate on this footnote? Is this the successful tipping case that was overturned on appeal.

$20 \quad$ The key recent Canadian case highlighting these substantive issues is R. v Felderhof 2007 ONCJ 345. 
staffing levels and "enforcement intensity", which he defines as "the frequency and severity with which a country's legal regime imposes sanctions on capital market participants." He finds that "Canadian enforcement activity is less intensive [in many areas] than U.S. enforcement activity" (Jackson, 2006 at 82). Between 2002 and 2004, the differences between the two countries were "so huge that they swamp[ed] any possible scaling adjustment [for market size]." While public enforcement activity in Canada has increased in recent years, Jackson reports that it is still lower than U.S. activity even taking into account scaling issues. Jackson's findings suggest that Canadian firms cross-listed in the U.S. face a greate threat of enforcement than non-cross-listed Canadian firms.

Because of lax public enforcement and the rarity of private ${ }^{21}$ enforcement, insider trading is thought to be quite rampant in Canada (The Globe and Mail, 2001; Canadian Insider Trading Task Force, 2003). Indeed, McNally and Smith (2003) present "large-scale" evidence of insider trading and reporting violations in Canada. Similarly, Bris (2005) finds that insider trading profits prior to the public announcement of mergers are the highest in Canada among the 52 countries in his study. Thus, if Canadian firms perceive insider trading as economically harmful, they ought to be inclined to enact private restrictions via ITPs. We empirically investigate this issue in Part 5, after presenting our testable hypotheses and methodology in Part 4.

\section{Hypotheses and Empirical Methodology}

\section{Hypotheses}

\footnotetext{
$21 \quad$ Theoretically, shareholders may privately enforce Canadian insider trading legislation by bringing bring class action lawsuits. Shareholder class actions are rare in Canada, however, mainly because of the rejection of the "fraud on the market" doctrine in Ontario (Carom v Bre-X(1998)). Canadian shareholders in theory may also launch an oppression remedy stemming from breach of an ITP by insiders. Corporate statutes in Canadian provinces allow complainants to apply to a court for an order that would remedy any action of a corporation, its affiliates or its directors that is "oppressive or unfairly prejudicial to or that unfairly disregards the interests of any security holder, creditor, director or officer." To our knowledge, however, such a case (i.e., for breach of an ITP) has never been brought.
} 
A point forcefully made by some in the insider trading debate is that firms did not voluntarily prohibit insider trading prior to its legal prohibition (Carlton and Fischel, 1983). From this observation, some scholars conclude that firms generally desire (or do not disapprove of) insider trading (see, e.g., Carlton and Fischel, 1983). It is true that most firms did not voluntarily prohibit insider trading prior to legal intervention, but the argument from history would be compelling only if markets were perfectly efficient, and even then it may not apply to the situation today. Markets are not, however, perfectly efficient, and the reality is that many U.S. and Canadian firms do voluntarily prohibit insider trading through ITPs, which supplement mandatory insider trading laws. In the empirical portion of this paper we shall examine the characteristics of firms that do and do not adopt ITPs as well as identify the types of firms most likely to go beyond what the law requires in enacting ITPs. This analysis does not directly examine the efficiency of insider trading regulation but does bear on it and suggests, as we explain below, that at least some firms and shareholders do not perceive unregulated insider trading as efficient.

For the purpose of predicting which firm characteristics are associated with the adoption of an ITP, we assume that, other things equal, a firm is more likely to have an ITP and, if it has one, to have one stricter than what Canadian law requires: (1) the greater the opportunity for insider trading, (2) the greater the potential costs of insider trading, and (3) the greater the potential benefits from preventing insider trading. These assumptions motivate our specific hypotheses, which, in summary form, are that ITP existence and ITP stringency are positively associated with: (1) firm size, (2) a firm's market-to-book ratio, (3) concentrated share ownership/control, (4) firm-specific stock return volatility, and (5) cross-listing on a U.S. stock 
exchange. Before turning to our data and analysis, we explain these hypothesized relationships in greater detail.

\section{Hypothesis 1: Larger firms are more likely to have an ITP than smaller firms}

There are several reasons, not mutually exclusive, why larger firms may be more likely to have an ITP than smaller firms. First, as Bettis et al. (2000) suggest, larger firms are likely to have greater numbers of insiders than smaller firms, making insider trading a more salient issue for the former than for the latter. Second, "[1]arger firms are more likely [than smaller firms] to have the organizational [or bureaucratic] ability to monitor and restrict insiders" (Roulstone, 2003, p. 544). Thus, building ITP monitoring and enforcement into organizational procedures will be easier for larger firms than for smaller firms. Third, larger firms tend to have more powerful outside shareholders (e.g., pension funds) than smaller firms (O’Brien and Bhushan, 1990), so insider trading may occur at the expense of more powerful outside interests in the former firms. Finally, larger firms face a higher level of public scrutiny from analysts and the broader investing public than smaller firms (O’Brien and Bhushan, 1990), suggesting that they are more susceptible to negative publicity stemming from the perceived unfairness and potential criminality of insider trading. This can harm a firm's image and its business generally.

Demonstrating compliance or super-compliance ${ }^{22}$ with insider trading laws by adopting an ITP may make a firm more attractive to investors who know that corporate scandals can lead to sharp falls in share prices. Relatedly, larger firms may see themselves as business leaders and, as ITPs are considered best practices, may want to jump on that bandwagon. Greater public scrutiny may also motivate larger firms to adopt ITPs they do not intend to enforce merely for window dressing purposes.

22 We shall use this term to refer to ITPs that are more restrictive than Canadian law. 
In addition, larger firms may be more likely than smaller firms to possess other characteristics that we expect to be associated with compliant and super-compliant ITPs - crosslisting on a U.S. exchange, for example. But we are only concerned here with associations net of other variables in our model.

Hypothesis 2: Firms with higher market-to-book ratios are more likely to have compliant or super-compliant ITPs than firms with lower market-to-book ratios

We predict that firms with higher market-to-book ratios - stock price relative to book value per share ${ }^{23}$ - are more likely to adopt ITPs because they tend to have greater asymmetric information and growth opportunities, both of which increase insider trading opportunities. These firms tend to have a greater proportion of intangible assets, like intellectual property, which makes it harder for outsiders to evaluate them and gives insiders a distinct informational advantage vis-à-vis outsiders, thus increasing the potential profitability of insider trading. On the contrary, a mature business with a lower growth profile and predictable earnings present fewer opportunities for insider trading. Consistent with Hypothesis 2, Bettis et al. (2000) find that insider trading activity is positively related to a firm's market-to-book ratio. Thus, if firms see insider trading as harmful to their interests, they ought to be even more inclined to do so the higher their market-to-book ratio. On the other hand, if powerful insiders are rent seekers or believe insider trading enhances corporate efficiency, they ought to be less likely to complement the law's restrictions by enacting ITPs. For hypothesis testing purposes, we assume firms are, in most cases, motivated to control insider trading.

23 A high market-to-book ratio means that the company's market valuation is greater than the value of its assets. Firms with high market-to-book ratios tend to have a greater degree of intellectual property, which is inherently more speculative and thus more difficult to value than physical assets. 


\section{Hypothesis 3: Firms with more concentrated share ownership/control are more likely to} have compliant or super-compliant ITPs than firms with less concentrated share ownership/control

As an initial matter, one may wonder why ITPs that restrict trading by insiders would even be relevant to controlling shareholders. ${ }^{24}$ Like insider trading laws, however, ITPs prohibit insiders from tipping outsiders, which includes controlling shareholders who may otherwise solicit tips from insiders. In addition, in Canada, many controlling shareholders are also officers (e.g., the CEO who owns $20 \%$ of the firm's voting shares) or directors (Daniels and Morck, 1995) and thus subject to ITPs. Thus, controlling shareholders are at least indirectly subject to ITPs and may be directly subject to them as well if they are also corporate officers or directors. As with Hypothesis 2, one could argue that this factor should diminish rather than increase efforts to control insider trading. Demsetz (1986) and Bhide (1993), for example, argue that concentrated ownership is desirable because large shareholders engage in valuable corporate monitoring, reducing agency costs. Furthermore, because of their greater ownership stake, large shareholders have greater access to inside information and are able to make superior trading profits relative to other shareholders (Demsetz, 1986; Bhide, 1993). These profits, in the view of these theorists, are not windfalls, but rather compensate large shareholders for their monitoring activities and for the risks attendant to holding undiversified portfolios (Demsetz, 1986; Bhide, 1993). Restricting such compensation by prohibiting insider trading may reduce their incentives to monitor (Demsetz, 1986; Bhide, 1993), by raising the costs and liabilities of active shareholding and monitoring (Bhide, 1993). ${ }^{25}$ This implies that firms that value large

24 In Canada, controlling shareholders are legally classified as insiders if they hold $10 \%$ or more of the firm's voting securities. Section 1.1, Securities Act (Ontario).

$25 \quad$ Both Demsetz (1986) and Bhide (1993) oppose insider trading restrictions for precisely this reason. 
shareholder monitoring may shun ITPs or adopt ITPs that exempt dominant shareholders who are corporate outsiders.

In contrast, Maug (2002) worries that large shareholders will serve their own interests at the expense of minority shareholders if they are permitted to engage in insider trading. ${ }^{26} \mathrm{He}$ argues that allowing insider trading may lead large shareholders to seek profits not by monitoring managers in ways that foster the interests of most investors but by using private knowledge to expropriate the wealth of outside investors. Maug argues that allowing insider trading may enable managers to "bribe" dominant shareholders to forego monitoring the firm when it is performing poorly by sharing private information with them. If the firm's stock is sufficiently liquid, trading on such information will provide greater profits than can be gained through close monitoring and efforts to improve firm performance. ${ }^{27}$ Thus, firms with concentrated ownership may desire insider trading restrictions to reduce agency costs and encourage minority shareholders to invest in the firm. Contrary to the prediction that would seem to flow from Demsetz' (1986) and Bhide's (1993) analyses, this logic implies that firms with concentrated ownership may be more likely to adopt an ITP, thus pre-committing to restrict trading by dominant shareholders (who, in Canada, are likely to overlap significantly with insiders) at the expense of minority shareholders. In addition, non-insider controlling shareholders (e.g., institutional investors such as mutual funds, pension funds, and the like) may wish to prevent insider trading to reduce managerial agency costs.

26 Along similar lines, La Porta et al. (1999) suggest that the primary agency problem in firms with controlling shareholders is the expropriation of minority shareholders. The implication is that the law should be concerned not only with preventing managerial value diversion but also with containing expropriation by large shareholders (see, e.g., La Porta et al., 1998; La Porta et al., 1999; and Bukart and Panunzi, 2006).

27 Maug (2002) demonstrates that, conditional on the stock's liquidity, when insider trading is legal, dominant shareholders are more likely to collude with managers at the expense of minority shareholders in exchange for trading profits, whereas when insider trading is illegal, dominant shareholders are more likely to monitor managers than to trade. 
As with Hypothesis 2, we shall assume for hypothesis testing purposes that our variable of interest here, control shareholding, correlates positively with firm policies to ban insider trading.

Hypothesis 4: Firms with greater firm-specific stock return volatility are more likely to have an ITP than firms with less firm-specific stock return volatility

Firms with a higher degree of firm-specific (or idiosyncratic) volatility of their stock returns relative to the total volatility of their stock returns have a greater flow of firm-specific news into their share prices (Morck et al., 2000; Fox et al. 2003). These firms are likely to present more profitable insider trading opportunities than firms with relatively lower firmspecific volatility as a share of total volatility:

Firm-specific risk...is a plausible measure of the profit potential of insider trading....High firm-specific risk firms are those whose fortunes tend to be tied to factors that do not influence many other firms. Information about common factors... will be known in advance to many persons in many firms that stay in contact with capital markets. Profiting from this information is difficult because intensive competition to do so is faced from all who are well positioned to have the same information. In contrast... advanced knowledge about a successful closing in a new large contract is more likely to be restricted to persons in firms doing the contracting. Trading on the basis of such firm-specific information is likely to be less competitive and more profitable. It is information that impacts the fortunes of a specific firm that provides the best opportunity to profit. Such information is most frequently encountered in those firms exhibiting high firm-specific risk (Demsetz, 1986, pp. 314-315, emphasis added). ${ }^{28}$

Again, however, the normative assessments and empirical expectations of different theoretical perspectives conflict. One may argue that because insider trading opportunities are likely to be more plentiful in firms characterized by relatively greater firm-specific risk, these firms will be more prone to adopt a compliant or super-compliant ITP. Conversely, to the extent that insider 28 Consistent with this, Demsetz (1986) finds a strong positive correlation between insider trading and firmspecific risk. 
trading increases the flow of firm-specific information into stock prices (see Manne 1966; Carlton and Fischel, 1983), restricting insider trading will result in stock prices that reflect less firm-specific information. Firms that think that over time this will harm markets in their stock other financial instruments may feel they would be disadvantaged by adopting an ITP, especially a super-compliant one. In the latter case, where firm-specific volatility is endogenous to the ITP, we may observe a negative relationship between firm-specific volatility and ITPs or ITP strictness. $^{29}$

In addition to firm-specific volatility, we also consider total volatility, since higher overall volatility may enable insiders to mask their trades more effectively (Kraakman, 1991). If insiders are able to mask their trades, other things equal, insider trading will be more profitable and therefore more likely. Again, however, we have no a priori directional expectations. Firms with greater total return volatility may be more likely to restrict insider trading than firms with lower total return volatility because there is a greater chance it will happen. Conversely, a lower danger of discovery and hence scandal may make a firm less likely to adopt an ITP, particularly since insiders who determine whether to adopt an ITP will see a good chance of avoiding detection by external monitors in situations of high total volatility but will have more to fear if there is internal monitoring as well.

As in other situations where the empirical implications of different perspectives conflict, we pose our expectations in their positive form for empirical testing purposes. Thus, we hypothesize that both greater firm-specific return volatility and greater total return volatility of stock returns increase the likelihood that a firm will adopt a compliant or super-compliant ITP. 
Hypothesis 5: Firms that are cross-listed in the U.S. are more likely to have compliant or super-compliant ITPs than firms that are not cross-listed in the U.S.

The "bonding" hypothesis suggests that firms from jurisdictions with weaker shareholder protections have a strong incentive to cross-list their shares into foreign markets with stronger shareholder protections (Reese and Weisbach, 2002; Coffee, 2002; Doidge et al. 2004). By bonding themselves to a more stringent regulatory regime, firms may reduce their agency costs and attract greater outside investment. Korczak and Lasfer (2006) demonstrate that insiders of U.K. firms cross-listed in the U.S. are less inclined to trade on private information than noncross-listed U.K. firms because of their dual exposure to U.S. and U.K. insider trading regulations. Furthermore, evidence suggests that firms cross-listed on a stock exchange in a foreign country with a more stringent regulatory regime than in the home country are more likely to voluntarily adopt stringent governance standards than non-cross-listed firms (Anand, Milne and Purda, 2006). We expect a similar pattern to hold for voluntary adoption of ITPs among Canadian firms cross-listed into the U.S. because the probability that insider trading laws will be publicly enforced is greater in the U.S. than in Canada and, as noted above, ITPs are a defense to corporate liability in the U.S. Canadian firms cross-listed into the U.S. also face a greater risk of a secondary market class action lawsuits (i.e., private suits) than non-cross-listed Canadian firms. ${ }^{30}$ Super-compliant ITPs can be a useful defense to class actions by negating corporate scienter, an element that must be proven in securities class action lawsuits in the U.S. (see, e.g., City of Monroe Employees Retirement Sys. v. Bridgestone Corp., 387 F.3d 468 ( $6^{\text {th }}$ Cir. 2004)) but, notably, not in Canada. Arguably, the more stringent the ITP, the greater the public and private liability shield.

$30 \quad$ See note 21 , infra. 
Our hypotheses predict what types of firms are likely to have an ITP in the first instance and, among firms that have an ITP, which of them will have an ITP that is stricter than Canadian insider trading law. We test these hypotheses in Part 5 after presenting our empirical methodology and data.

Table 1 summarizes our hypotheses.

\section{Data, Empirical Methodology, and Results}

\section{Data Overview}

Our initial sample consisted of firms included in the TSX/S\&P Index as of December 31, 2005. We obtained the list of firms from the Market Data group at the Toronto Stock Exchange. We were able to collect data on 202 of the 206 firms (or 98\%) in the index. We then excluded financial firms and income trusts from our analysis, yielding a final sample of 181 firms. ${ }^{31}$ Our variables fall into two categories. The first category consists of variables describing whether a firm has an ITP and the features of the firm's ITP, if it has one. The second category consists of various firm characteristics that we use to test our hypotheses. Descriptions of both categories of variables follow.

\section{Characteristics of Firms' Insider Trading Policies}

Our first task was to determine whether or not each firm has an ITP by referring to the System for Electronic Document Analysis and Retrieval (SEDAR), which is available online, and to firms' websites. ${ }^{32}$ If so, we gave the variable ITP the value one and, if not, we gave it the value zero. We could not get reliable data on private ITPs. We assume, however, that if they

31 We excluded financial firms because this is the standard practice in the corporate finance literature (see, e.g., La Porta et al., 1998) We excluded unit trusts because their structure differs significantly from the corporate structure utilized by the firms in our sample. Specifically, the business of the trust continues in an underlying operating corporation and the trust holds all of the debt of the corporation but exists primarily as an investment vehicle whose governance structure is not regulated by corporate law.

32 The website www.sedar.com contains most of the public documents and information filed by Canadian public companies and investment funds with the Canadian Securities Administrators (CSA) in the SEDAR filing system. SEDAR online is the Canadian equivalent of EDGAR online for U.S. public corporations. 
exist they are few in number because they would not play the signaling role of reassurance to outside investors or legal compliance that are likely major reasons for adopting ITPs.

After determining whether a firm has an ITP, we collected additional information on each ITP. First, we coded whether the ITP is a separate public document or is contained in a published code of conduct or another publicly available document. In some cases, the ITP is described in a required disclosure document, such as an information (or proxy) circular. In other cases, the ITP is referenced but is not described or discussed in the disclosure document.

We also recorded whether the firm's ITP is more stringent than Canadian legal requirements or whether it simply restates Canadian insider trading law. ${ }^{33}$ We measure stringency with two variables. Our first measure of ITP stringency is the variable Stringent, which we coded as one if a firm's ITP contains a blackout period(s), provides for the appointment of an internal trading officer or monitor, and/or includes a procedure for employees to apply to trade during the blackout period, none of which is required by Canadian law. ${ }^{34}$ If an ITP contains none of these provisions and merely mimics the requirements of Canadian law, we coded Stringent as zero. ${ }^{35}$ If an ITP is ambiguous or unclear for any reason (e.g., if the publicly available documents contain only a vague description of the policy or none at all), we code Stringent as a missing value. ${ }^{36}$ Our second measure of ITP stringency is whether an ITP contains a clause under which the firm can levy its own (i.e., private) penalties against insiders who have breached the firm's ITP or Canadian insider trading law. If so, the variable Private

\footnotetext{
33 For a review of the requirements of Canadian insider trading law, see Appendix 1.

34 These three characteristics are all suggested best practices in National Policy 51-101, as noted above. We do not distinguish ITPs by the number of ways in which they exceed Canadian legal requirements.

35 For example, if an ITP contains only a prohibition on trading while an "insider" is in possession of material nonpublic information, but no additional requirements over and above this legal requirement, we classified the policy as being as strict as Canadian law.

36 Arguably, we should code Stringent as a zero if a firm's ITP is ambiguous or unclear, since a firm has an incentive to reveal that it follows a recommended best practice and to communicate extra protection to investors. Our results do not change, however, if we replace missing values of Stringent with zero.
} 
Penalty equals one and, if not, Private Penalty equals zero. Below, we use both stringency variables to create a more nuanced ordinal ranking of ITP stringency.

\section{Firm-Specific Characteristics}

To test our hypotheses about the kinds of Canadian firms that are likely to have ITPs, we collected the following firm-specific information for each firm: three measures of the firm's size (stock market capitalization, net sales, and total assets), the firm's market-to-book ratio, the number of shareholders who own more than $10 \%$ of the firm's voting shares (i.e., the number of controlling shareholders), the total (average) percent of the firm's voting shares owned by the firm's controlling shareholders (each controlling shareholder), the firm's monthly closing stock prices from January, 2002 through December, 2005 (inclusive), which we used to calculate monthly stock returns and the volatility of such returns, as described below, and, finally, whether the firm's shares are cross-listed on a U.S. stock exchange. We downloaded the accounting measures and information on U.S. cross-listing from the Standard \& Poor's Compustat database, which is available online. To verify our information on cross-listing, we also checked SEDAR and company websites, where necessary. We calculated the ownership and control variables based on information supplied by firms through their public disclosures (proxy circular or annual information form) that are available on SEDAR. We gathered monthly stock prices from Standard \& Poors Compustat. In a few cases, we supplemented these data with stock prices reported by Datastream or Yahoo.com.

In our multivariate regressions we also control for a firm's industry, as defined by the North American Industry Classification System (NAICS) to account for the fact that firms in some industries may be more prone to insider trading because of the nature of their assets. For example, we expect firms with a greater proportion of intangible assets relative to total assets to 
be more likely to have ITPs than firms with a lower proportion of such assets because the former firms are characterized by a relatively greater degree of asymmetric information, which increases the opportunities for insider trading. ${ }^{37}$ Controlling for industry addresses this issue to the extent that the nature of corporate assets differs systematically across industries. We use 3-digit NAICS industry codes, which we downloaded from the online Standard \& Poors Compustat database.

\section{Volatility of Stock Returns}

As noted above, we consider two types of stock return volatility: total stock return volatility and firm-specific stock return volatility. We measure total stock return volatility as the standard deviation of monthly stock returns between January, 2002 and the end of 2005, inclusive. This measure of volatility is admittedly naïve in that it does not distinguish between stock return variation that is common to all stocks in the market and stock return variation that is unique to a specific firm. For the reasons discussed above, we expect the latter form of stock return volatility to have a greater influence on the incentive to engage in insider trading than volatility that is common across all firms' stocks. As we have noted, information that is common to the entire market does not yield significant opportunities for profitable insider trading. Therefore, we expect firm-specific volatility to be more strongly related than total volatility to the propensity for a firm to adopt a compliant or super-compliant ITP.

Accordingly, our second and theoretically more important volatility measure is firmspecific stock return volatility, which is considered a proxy for firm-specific information in the finance literature (Roll, 1988; Durnev et al., 2003). We use Roll's (1988) methodology for estimating firm-specific stock return volatility). The measure varies from 0 to 1 , with a value of

$37 \quad$ Firms with a greater degree of intangible assets have greater asymmetric information because these assets are harder for outsiders to value than tangible assets. 
1 indicating that $100 \%$ of the variation in a firm's returns can be attributed to firm-specific considerations and a value of 0 indicating that none of the variation in a firm's returns can be attributed to firm-specific factors or, equivalently, $100 \%$ of the variation in a firm's returns is explainable by changes in the market return. ${ }^{38}$

We summarize our data and their sources in Table 2.

\section{Descriptive Statistics}

Table 3 presents data on the prevalence of ITPs among the firms in our sample. Of the 181 firms in our final sample, 144 (about 80\%) have an ITP and 37 (about 20\%) do not have an ITP. Thus, more than two-thirds of the firms in our sample of TSX firms have an ITP.

Table 4 presents information about where our sample firms publicly document their ITPs. An ITP may appear publicly as a standalone document, in the company's code of conduct, or it may be referred to in another publicly available corporate document, such as an information (or proxy) circular. Among the 144 firms that have an ITP, such policies appear in a standalone document in 26 cases (18\%), in a code of conduct in 43 cases (30\%), and by reference in another corporate document in 70 cases (49\%). Thus, the majority of ITPs in our sample are incorporated by reference into another corporate document, like a code of conduct, and standalone documents are the least common place where ITPs publicly appear. This classification is relevant in terms of discerning the substantive content of the ITP. A publicly available standalone document generally contains all of the terms of the ITP, while an ITP that is merely referenced in another disclosure document generally does not contain the full details of the particular ITP's provisions.

38 In brief, firm-specific stock return volatility is calculated as $1-\mathrm{R}^{2}$ from the "market model" ordinary least squares regression of the firm's monthly stock returns on the market index. See Appendix 2 for a more detailed description of how we calculate firm-specific stock return volatility. 
The reader will recall that we classify a firm's ITP as stricter than Canadian insider trading law if the policy contains blackout period(s), provides for the appointment of an internal trading officer or monitor and/or consists of a procedure for employees to apply to trade during the blackout period(s). These are suggested best practices in a national policy statement but they are not legal requirements. In contrast, we classify an ITP as being as strict as Canadian insider trading law if it mimics or simply restates existing law. Also recall that we ascertain whether an ITP permits the firm to levy its private penalties (e.g., unpaid leave, dismissal, or fines) against insiders who have breached the firm's ITP or Canadian insider trading law. Among the 144 firms that have an ITP, we were able to determine ITP strictness (relative to Canadian law) for $138(96 \%$ of the firms that have an ITP) and whether the firm may exact its own penalties for violations for 143 (99\% of the firms that have an ITP). Thus, we have information on both strictness and private penalties for 138 of the 144 firms that have an ITP, or $96 \%$ of these firms. In the remainder of cases ( $4 \%$ of the firms that have an ITP), the respective information was unavailable, incomplete, or ambiguous.

Table 5 presents cross-tabulations between ITP stringency and the existence of private penalties. Several interesting patterns are apparent in this table. First, slightly more than half $(52 \%)$ of the firms that have an ITP have an ITP that is no stricter than Canadian insider trading law, while $44 \%$ of these firms have an ITP that goes beyond the law. Second, three quarters of the firms that have an ITP also have a private disciplinary mechanism to enforce the firm's ITP. This is some, but certainly not dispositive, evidence that firms that have ITPs do not in many instances see them as mere window dressing. Finally, 75\% of firms whose ITPs demand no more than Canadian law have private penalties, so in this sense even the ITPs of these firms are 
more stringent than Canadian insider trading law since they provide an additional, and perhaps more likely to be realized, penalty for violation. ${ }^{39}$

Table 6 presents summary statistics for our explanatory variables, i.e., the firm-specific characteristics. As we expected, because they are firms in the TSX/S\&P Index, the firms in our sample are very large. Just over two-thirds ${ }^{40}$ of the firms have a controlling shareholder and the average number of controlling shareholders per firm is about one. For the firms for which we could determine share ownership of the controlling shareholder(s), such shareholder(s) own an average of $41 \%$ of the firm's voting shares, which translates into an average of about $32 \%$ of the voting shares per controlling shareholder per firm. ${ }^{41}$ The average total volatility of monthly returns between 2002 and 2005 is $13 \%$ and the average firm-specific volatility is $92 \%$ (i.e., general market changes explain an average of only $8 \%$ of monthly volatility of returns). ${ }^{42}$

Panel A of Table 7 compares various firm-specific characteristics between the firms with and without ITPs. The data are in accord with Hypothesis 1, as the firms that have an ITP tend to be larger than the firms that do not have an ITP, where size is measured by market capitalization, net sales, or total assets. By contrast, there is no statistically significant difference in the market-to-book ratios of the firms with and without ITPs, and the direction of the difference is contrary to Hypothesis 2 . There is similarly no difference in the incidence of controlling shareholders, the number of controlling shareholders, or the average percent of votes owned per controlling shareholder between firms with and without ITPs. Controlling

39 Table 5 shows that among the firms that have an ITP, we are most likely to observe an ITP that is as strict as the law and enables the firm to levy private penalties and we are least likely to observe an ITP that goes beyond the law and does not provide for private enforcement.

40 This result is consistent with prior studies that find that corporate ownership concentration is relatively high in Canada (see, e.g., Daniels and Morck, 1995).

41 Because we have so few observations on share ownership of the controlling shareholders, we do not use these variables in the regression analyses below.

42 Although the average value of the firm-specific volatility measure (1 minus adjusted R-squared) seems quite high, at .92, it is roughly consistent with Roll's (1988) findings. 
shareholders do tend, however, to own a greater fraction of voting shares among the firms that have an ITP than among the firms that do not have an ITP and the difference is significant at the 5\% level, a result consistent with Hypothesis 3. Contrary to Hypothesis 4, firms without an ITP tend to have greater total volatility in monthly returns than the firms that have an ITP, and the difference is significant at the 5\% level. Firm-specific volatility is also not associated with ITPs. Finally, contrary to Hypothesis 5, the difference in the incidence of cross-listing in the U.S. between the firms with and without an ITP is insignificant, though the direction of the difference is as predicted and reasonably large.

Panel B of Table 7 compares firm-specific characteristics between the firms whose ITPs are stricter and those whose ITPs are as strict as Canadian insider trading law. Most of the firmspecific characteristics do not significantly differ between the two sets of firms. Only the incidence of a controlling shareholder and the number of controlling shareholders differ significantly between these firms, consistent with Hypothesis 3. The firms with super-compliant ITPs are more likely to have a controlling shareholder than the firms with an ITP that merely matches Canadian insider trading law, a difference that is significant at the $10 \%$ level. These firms also have, on average, a greater number of controlling shareholders than firms whose ITPs are less strict than Canadian insider trading law, a difference that is significant at the $1 \%$ level. In addition, the firms with stricter ITPs tend to have a higher average percent of votes owned per controlling shareholder than firms with ITPs that are equally strict as Canadian insider trading law, consistent with Hypothesis 3, but the difference only approaches significance. ${ }^{43}$ The former firms also have greater average firm-specific return volatility, consistent with Hypothesis 4, but the difference is not significant at a conventional level. ${ }^{44}$ As predicted by Hypothesis 5, the

43 The significance level is $11 \%$, which is not significant at a conventional level.

44 The significance level is $15 \%$, which is not significant at a conventional level. 
firms that have a super-compliant ITP are more likely to be cross-listed in the U.S. than the firms with merely a compliant ITP, but the difference in cross-listing incidence between these two sets of firms is insignificant. Finally, the firms with super-compliant ITPs are not more likely to have a private penalty mechanism than the firms with ITPs that merely meet the requirements of Canadian law.

Table 8 presents bivarate correlation coefficients for our dependent and explanatory variables. The relationships between firm characteristics and ITP existence and stringency are as seen in the bivariate tables, although the correlation coefficients give us an idea of the strength of these relationships. Even when they are significant, the strengths of these correlations are low to, at best, moderate, ranging from an absolute value of 0.01 to an absolute value of 0.25 . Interestingly, the existence of private disciplinary mechanisms bears no statistically significant relationship to either the existence of an ITP or its strictness, nor to any of the firm-specific characteristics. Our three measures of firm size are closely associated, as we expected, with correlation coefficients ranging from 0.60 to 0.70 and statistically significant at the $1 \%$ level. Market capitalization is inversely related to the existence and number of controlling shareholders, as one may expect, but it is positively related to the votes owned by controlling shareholders and the average number of votes owned per controlling shareholder; all of these relationships are significant at the $5 \%$ level or better. Firm size, as measured by net sales, has no relationship to the first two of these variables, but has a similar and somewhat stronger relationship to the last two at a significance level of 1\%. Larger firms, as measured by market capitalization, are more likely to be cross-listed than smaller firms and the correlation coefficient is significant at the $1 \%$ level. 
Table 8 also shows that firms with a greater market-to-book ratio are less likely to have a controlling shareholder and, on average, have fewer controlling shareholders and less aggregate votes held by controlling shareholders. Firms with higher market-to-book ratios also tend to have greater total volatility of stock returns (correlation coefficient is significant at the $1 \%$ level) but they do not have greater firm specific-volatility of returns, compared to firms with lower market-to-book ratios. Perhaps not surprisingly, firms with controlling shareholder(s) are less likely to be cross-listed in the U.S. As one may expect, the number of controlling shareholders is negatively related to the average number of votes owned per controlling shareholder. The total number of votes owned by controlling shareholders is strongly associated with the average number of votes owned per controlling shareholder (correlation coefficient $=.81$ ). Finally, firms with greater firm-specific volatility are less likely to be cross-listed on a U.S. stock exchange.

Our descriptive statistics provide initial insight into the types of Canadian firms that are likely to have an ITP or an ITP that is stricter than Canadian law. They tell a mixed story. Some factors that may be expected to be associated with compliant or super-compliant ITPs do show a significant association but the magnitude of the association is often small and neither of the theoretical perspectives that can motivate the hypotheses is consistently supported. Moreover, several of the relationships we found support neither of the conflicting perspectives because they are not significant in either direction. To check on the reliability of these results, we now turn to our multivariate analysis.

\section{Empirical Methodology}

\section{Ordinary Probit Regression}

We shall examine two dependent variables $\left(Y_{1}\right.$ and $\left.Y_{2}\right)$ : for each firm in our sample, $\mathrm{Y}_{1}$ equals 1 if the firm has an ITP and 0 if the firm does not have an ITP and, for the subset of firms 
that have an ITP, Y 2 equals 1 if the firm's ITP is more restrictive than Canadian insider trading law and 0 if it does no more than match the requirements of Canadian insider trading law. Since both dependent variables are dichotomous, i.e., equal to either 0 or 1 , we use a probit model to estimate the conditional probability that each equals 1 , that is:

$$
\operatorname{Pr}\left(Y_{i}=1 \mid X=x\right)=\Phi\left(x^{\prime} \beta\right),
$$

where $\Phi$ is the cumulative distribution function of the standard normal distribution, $x$ is a vector of explanatory variables, and $\beta$ is a vector of regression coefficients that explain the relationship between the dependent variable and the explanatory variables. The probit model posits that the probability that the dependent variable (ITP existence or ITP stricter than Canadian insider trading law) equals one is a function of the explanatory variables, which in our case are the firmspecific characteristics described above.

\section{Ordered Probit Regression}

The simple dichotomization of ITP stringency above may not quite capture the relative stringency of corporate policies. For instance, a firm with an ITP that does not go beyond Canadian statutory requirements but provides for internal (private) sanctions may nevertheless have a more stringent corporate policy on insider trading than a firm that has similar rules but does not provide for internal (private) sanctions. Thus, in addition to the standard probit analysis described above, we also conduct an ordered probit analysis, to accommodate a more refined ordinal ranking of ITP policy options. The ordered probit model takes the following form:

$$
\operatorname{Pr}(Y=1,2,3, \ldots, n \mid X=x)=\Phi\left(x^{\prime} \beta\right),
$$

where the dependent variable, $Y$, equals a discrete value between 1 and n, with higher values of $Y$ indicating a more stringent corporate policy toward insider trading. In this model, the probability that the dependent variable equals $1,2,3, \ldots$, or $n$ is again a function of the firm-specific 
characteristics described above. We describe the ordinal ranking of the dependent variable, which is a function of both formal corporate rules and private sanctions, below.

Results

Ordinary Probit Results

As described above, we first estimate an ordinary probit regression for two dependent variables, ITP existence and ITP strictness relative to Canadian insider trading law. The reader will recall that we presented five testable hypotheses predicting ITP existence and stringency (see Table 1). The first four were somewhat arbitrary in their direction as there are competing theoretical perspectives in the literature, some of which indicate that insider trading makes firms and markets worse off and some of which suggest it makes them better off, and these perspectives have opposite implications for how we should expect our independent variables to behave. We cast our hypotheses to favor the former perspective, partly for convenience sake and partly because both the recent comparative empirical research and the fact that insider trading is everywhere banned suggest that insider trading is economically more harmful than beneficial. Our fifth hypothesis, that listing on a U.S. stock exchange is positively associated with ITP existence and stringency, is more a matter of common sense than of theory since cross-listed firms are subject to the greater liability risk than non-cross-listed firms. The explantory variables $-\log$ of stock market capitalization ${ }^{45}$, market-to-book ratio, a dummy $(0,1)$ variable for the presence of a controlling shareholder (or the number of controlling shareholders), firm-specific

45 In the interest of space, all of the regressions reported in this section use the log of stock market capitalization as the measure of firm size. However, the results are similar if we substitute either the log of sales or the $\log$ of assets for the log of stock market capitalization as a measure of firm size. 
volatility of returns ${ }^{46}$, and a dummy $(0,1)$ variable if the firm is cross-listed in the U.S. - test Hypotheses 1 through 5, respectively.

Panel A of Table 9 presents ordinary probit results for the existence of an ITP. The regressions in Columns (1) through (3) do not control for industry, while the regressions in columns (4) through (6) do. We shall focus our attention on model 6, as it is the richest model and, judging by the pseudo R-squares, it best explains whether a company will have an ITP. We see from model 6 in Panel A that Hypothesis 1 is supported. Larger firms are more likely to have ITPs than smaller firms. Perhaps this is because, while all firms may have incentives to control insider trading, larger firms face greater problems than smaller firms in doing so because they have more insiders. Larger firms may thus be more dependent on formal rules to control insider trading than smaller firms. It may also be because larger firms face greater scandal costs than smaller firms if their insiders' trading becomes publicly known. Alternatively, the significant results may reflect institutional factors that have little to do with the costs or benefits of allowing insider trading. Larger firms may simply have more rules or be more inclined to reduce their rules to writing or publicize information about their rules than smaller firms. The size effect may also reflect window-dressing.

Hypothesis 2, that firms with higher market-to-book ratios are more likely to have ITPs because they are more susceptible to insider trading than firms with lower market-to-book ratios, is unsupported by the data. The market-to-book variable is significant or marginally significant away from the predicted direction before controls for industry sector and the number of controlling shareholders are introduced into the model.

46 We do not report the results for total return volatility in any of the regressions below and, at any rate, total return volatility is always insignificant in our regressions. 
The results regarding Hypothesis 3, which predicts that the presence of controlling shareholders makes having an ITP more likely, are particularly interesting. We define the presence of controlling shareholders in two ways: first, whether there is at least one controlling shareholder and, second, the total number of controlling shareholders. The former variable is significantly associated with the absence of an ITP and the latter with its presence. Moreover, the presence of at least one controlling shareholder is not significantly associated with the presence of an ITP unless the total number of controlling shareholders is in the model. This suggests that when there is only one or a small number of controlling shareholders, ITPs are either thought less necessary (the controlling shareholder knows she will not engage in insider trading) or a hindrance (the controlling shareholder seeks the rents available through insider trading). When controlling shareholders increase in number, however, no controlling shareholder can be sure the others will not engage in insider trading, so an ITP may be adopted to guarantee against this. Alternatively, when there are more controlling shareholders, the costs of insider trading may exceed its benefits to each such shareholder, since they must compete among themselves for scarce insider trading profits. Thus, on balance, our data support Hypothesis 3 in a somewhat more nuanced manner than we expected.

Contrary to Hypothesis 4, firm-specific volatility has no relationship to the presence of an ITP, although once industry sector is controlled for, the relationship is in the predicted direction. Cross-listing on a U.S. stock exchange is also non-significant, although the coefficient is positive as predicted by Hypothesis 5.

As noted above, we hypothesize that the same factors that explain whether a firm has an ITP also explain, for the subset of firms that have an ITP, whether the ITP goes beyond Canadian law. Panel B of Table 9 presents ordinary probits results for ITP strictness. As in Panel A, the 
regressions in Columns (1) through (3) do not control for industry, while the regressions in columns (4) through (6) do. Focusing on model 6, we see that the variables that explain the strictness of an ITP, when one exists, differ from those that explain whether an ITP will exist in the first instance. The only variable whose effect seems unchanged is the number of controlling shareholders, which predicts both the existence of an ITP and a super-compliant ITP. Firmspecific volatility is insignificant in model 6 in Panel A for the existence of an ITP but it is positive and significant in model 6 in Panel B for the strictness of an ITP. This suggests that, consistent with Hypothesis 4, firms with greater idiosyncratic return volatility are more likely to have super-compliant ITPs than firms with lower idiosyncratic return volatility.

Still comparing model 6 between Panels A and B, all other variables see their significance reversed. Market capitalization, the size variable, and the presence of at least one controlling shareholder, which are significant when the existence of an ITP is the dependent variable, are insignificant when the strictness of an ITP is at issue. Indeed, the controlling shareholder variable may as well not be in the model in Panel B, for model 5 excludes it but paints the same picture as model 6 and has an identical pseudo R-square. Cross-listing in the U.S. and firm-specific volatility, which are insignificantly related to the presence of an ITP in Panel A, are significant when ITP strictness is at issue in Panel B. Finally, all relationships except the presence of at least one controlling shareholder are in the predicted direction. We have already given a more nuanced explanation of the latter result relative to Hypothesis 3 . Interestingly, in Panel B, when the presence of at least one controlling shareholder is in the model and the number of controlling shareholders is not, the variable is negative and significant. This result suggests that when a firm has at least one controlling shareholder and an ITP, the 
firm's ITP will require no more than what the law requires, perhaps evidence of window dressing. 47

There may be plausible explanations for some of the differences and the one similarity between the results in Panels A and B of Table 9. Rather than attempt to explain these differences here, however, we turn to the ordered probit results because the differences between Panel A and B may, as we contemplated above, simply derive from the rather crude categorization of our dependent variables in Table 9.

\section{Ordered Probit Results}

As noted above, our crude categorization of ITP stringency may not fully capture the relative stringency of corporate policies. Thus, we construct a more nuanced ordinal ranking of ITP stringency and use this ranking to estimate an ordered probit model. The dependent variable, Ordered_Stringency, whose value increases in ITP stringency, equals 1, 2, 3, 4, or 5. Ordered_Stringency equals 1 if the firm does not have an ITP, 2 if the firm has an ITP but no provision for private sanctions, 3 if the firm has an ITP and may impose private sanctions, 4 if the firm's ITP is more restrictive than Canadian insider trading law but does not provide for private sanctions, and 5 if the firm's ITP is more restrictive than Canadian insider trading law and the firm may impose private sanctions.

The ordered probit results are presented in column (1) of Table 10. The results in column (1) are consistent with the results of model 6 in Table 9, Panel B, where the dependent variable is our dichotomous measure of ITP stringency. However, they are more consistent with our hypotheses, since they support four out of five of them. Size is now significant in the predicted direction, whereas it is insignificant with our cruder measure of ITP stringency. The only

$47 \quad$ Recall that in Panel A, we find that having at least one controlling shareholder alone is not significantly related to the presence of an ITP. 
hypothesis for which we do not find support in column (1) of Table 10 is the market-to-book hypothesis. The results in column (1) suggest that our initial intuition about relative policy stringency was roughly correct.

It is possible, however, that our ordinal ranking is incorrect. For instance, we deem a firm with an ITP that is just as strict as Canadian insider trading law and private sanctions (ranking 3) to have a less stringent policy than a firm with an ITP that is stricter than Canadian insider trading law but no private sanctions (ranking 4). This ordering elevates formal rules over organizational sanctions, but the latter may be more important for deterrence purposes than the formal rules. Thus, we reverse the rankings 3 and 4 . The results of this order-switching exercise are presented in column (2). Unlike column (1), where four of our five hypotheses are supported, only two of our hypotheses are substantiated in column (2), suggesting that our reordered stringency ranking is incorrect. By contrast, in column (3) where the dependent variable ranks firms solely according to their formal rules (no ITP, compliant ITP, and supercompliant ITP) and excludes private sanctions, the results are virtually identical to the results in column (1).

Thus, it seems that firms' formal rules governing insider trading are more important than private organizational sanctions in producing our results. A possible interpretation is that having an ITP that is equally strict as the law and an internal enforcement mechanism does not offer a firm much more (e.g., in deterrence or liability avoidance) than Canadian insider trading law already offers, while having an ITP that is stricter than Canadian law, albeit without provision for private sanctions, offers more than existing law. This interpretation is substantiated by the fact that cross-listing in the U.S. becomes insignificant when we reverse stringency rankings 3 and 4 in column (2). In the U.S. having a more stringent ITP (formal rule) in place is, among 
other things, a stronger defense to corporate liability irrespective of private sanctions. Another possibility, which can support more than the compliance/liability avoidance rationale for ITPs, is that private sanctions are less relevant than public sanctions because private parties (including firms) are less able to detect insider trading than a public regulator with sophisticated surveillance technology, like the SEC (Dooley, 1980). ${ }^{48}$

\section{Sensitivity Analysis}

We impute the values of missing variables, by using both mean imputation and imputation by regression, thereby increasing the sample size. This does not change our results. Our results also do not change when we replace missing values of Stringency with the value 0 , as discussed in note 36.

\section{Conclusion}

While voluminous, the literature on insider trading provides little empirical evidence on firms' motives for privately regulating insider trading in the context of the near ubiquitous legal prohibition. In this article, we forge new ground by providing empirical evidence on this issue in a market where insider trading laws exist but are not vigorously enforced. Using data on Canadian firms included in the TSX/S\&P Index, we attempt to understand the types, and indirectly the motives, of Canadian firms that privately regulate insider trading in spite, or perhaps because, of lax public enforcement.

Our data support most of our hypotheses. We find that larger firms are more likely than smaller firms to have both an ITP and an ITP that is stricter than Canadian insider trading law, i.e., a super-compliant ITP. In addition, we find that firms that have more than one controlling shareholder and firms that are cross-listed in the United States, where insider trading laws are more vigorously enforced than in Canada, are more likely to have both ITPs and super-compliant

$48 \quad$ Glaeser et al. (2001) address the general issue of public versus private regulation of stock markets. 
ITPs. We also find that Canadian firms whose stock returns exhibit greater firm-specific variation, suggesting greater insider trading opportunities, are more likely to have both ITPs and super-compliant ITPs than firms whose stock prices are more predictable based on general market trends. Thus, with our caveat about the results for controlling ownership, the market-tobook hypothesis is the sole hypothesis unsubstantiated by our data.

Our findings have several intriguing implications. First, while we cannot entirely rule out window dressing or the simple proclivity to enact and publicize ITPs, our results suggest there is more to the story than that. If window dressing fully explains ITPs, most, if not all, TSX/S\&P firms ought to have super-compliant ITPs because the stronger the policy, the more attractive the window. We find, however, that TSX/S\&P firms exhibit a range of organizational approaches to insider trading and that their choices are largely consistent with private cost-benefit considerations. That is, both the existence and stringency of ITPs are associated with firmspecific characteristics that roughly correlate with the private costs and benefits of restricting insider trading.

Second, our results are consistent with the compliance/liability avoidance rationale for ITPs. The clearest support for this is our finding that cross-listed firms are more likely to have super-compliant ITPs than non-cross-listed firms, suggesting that the stringent U.S. enforcement regime has a non-trivial extraterritorial effect on Canadian firms. Insider trading laws are more likely to be enforced in the U.S. against corporate insiders and firms, the latter pursuant to a theory of derivative liability, than in Canada. Canadian firms subject to the U.S. securities enforcement regime may shield themselves from liability by adopting ITPs and, we suspect, the more stringent the ITP, the more powerful the legal shield, as a court may be less inclined to disregard a maximal corporate policy than a de minimis one. A cynic may argue that the cross- 
listing effect demonstrates, at best, that firms will only do what the law requires and, at worst, the "imperialism" of U.S. securities enforcement. ${ }^{49}$

But compliance/liability avoidance cannot fully explain our results, nor can U.S. regulatory imperialism. In light of the lax Canadian enforcement regime, if compliance/liability avoidance were the sole raison d'etre of private insider trading restrictions, we would expect firm characteristics, except cross-listing status, to be insignificant. Yet, as noted above, our data do not show this and cross-listing is not the only factor relevant to ITP existence and stringency. On the contrary, controlling for cross-listing status, we find that several additional firm-specific characteristics which correlate with a firm's risk of insider trading systematically explain ITP existence and stringency. Having thus challenged pure window dressing and pure compliance/liability avoidance rationales for ITPs, we interpret the residual purpose for ITPs as the desire of at least some firms to control insider trading for economic, i.e., efficiency, reasons. Seen in this light, the cross-listing effect may reflect voluntary bonding for economic benefits rather than mere compliance/liability avoidance or, worse, U.S. regulatory imperialism.

Third, our finding that firms with more controlling shareholders are more likely to have both an ITP and a super-compliant ITP than firms with fewer controlling shareholders suggests that some shareholders, and influential ones at that, oppose insider trading. More specifically, influential shareholders may dislike insider trading when others are in as good a position to benefit from insider trading as they are, thereby reducing their trading profits. It also suggests that reality may be more nuanced than Bhide (1993) and Demsetz (1986) contemplate. In particular, controlling shareholders may prefer collectively tying their hands over competing among themselves for dissipating insider trading profits. Alternatively, consistent with Maug's (2002) analysis, some controlling shareholders may be outsiders (e.g., institutional investors)

49 For a critique of U.S. regulatory “imperialism” see Romano (2001). 
who wish to keep both insider controlling shareholders and managers in check (i.e., reduce agency costs) by prohibiting them from engaging in insider trading (see, e.g., Roulstone, 2003). ${ }^{50}$ The latter interpretation is consistent with Beny's (2008) finding of a positive relationship between insider trading law stringency and corporate valuation among firms with a controlling shareholder in common law countries. ${ }^{51}$

Fourth, and rather gratuitously, our findings suggest that formal organizational rules may dominate private sanctions in the present context. If so, they are more consistent with a norms or trust theory of organizational rules (see, e.g., Blair and Stout, 2001) than with an economic deterrence theory of such rules. Though it is intriguing, we ought not to oversell the point based on our limited data and we leave investigation of firms' normative attitudes to insider trading to future research.

Finally, this article contributes to the longstanding debate about the efficiency of insider trading regulation insofar as an influential claim in that debate is that firms do not desire to restrict insider trading. We document that some firms $d o$ wish to limit insider trading, often beyond what the law requires, and do so voluntarily in an environment where they face relatively little risk of public or private enforcement. Indeed, we think that, on net, our empirical results add to the case made by those who see insider trading as economically harmful. ${ }^{52}$ We concede,

50 The greater the number of controlling shareholders, the more likely some of them are to be outsiders. More cynically, dominant shareholders may prefer ITPs because they prevent insiders from trading, giving these shareholders a monopoly on trading profits. We doubt this explanation, however, because outside dominant shareholders' ability to profitably trade often depends on their receiving tips from insiders.

$51 \quad$ Beny's (2008) results suggest that outside investors may value the protection vis-à-vis insiders, and possibly also dominant shareholders, that strong insider trading laws provide.

$52 \quad$ As noted, our data support most of our hypotheses, which predict ITP existence and stringency on the assumption that insider trading on balance hurts firms and hurts those most vulnerable to insider trading the most. The marginal significance or insignificance of some of our results may result from small sample size, an issue we will correct in forthcoming research, by the possibility that our judgments about how our variables would affect the likelihood of insider trading are mistaken, or the possibility that although our judgments about the variables' implications are correct, firms that are more vulnerable to insider trading fail to perceive this. 
however, that our data do not prove this. ${ }^{53}$ Still, if there are strong negative effects to insider trading bans, as some have argued, nothing about the behavior of the firms in our data suggests this.

This article does not just contribute to the insider trading debate. Our pilot study also demonstrates the potential for learning more about the consequences of insider trading, particularly as perceived by firms, and about private insider trading bans through comparative research. To that end, we are substantially expanding our firm data to increase the power of our tests and enable further, more nuanced analyses.

For now, the surest conclusion is that the debate will continue, spurred on, we hope, by our findings.

53 In subsequent work, we will investigate the effects of voluntary ITPs on the amount of insider trading, share liquidity, agency costs, and the propensity to cross-list into the U.S. among adopting Canadian firms. 


\section{References}

A. Anand, F. Milne, L. Purda 2006, "Voluntary Adoption of Corporate Governance Mechanisms," Working Paper [on file with researchers].

K. Arrow, 1962, "Economic Welfare and the Allocation of Resources for Invention", in The Rate and Direction of Economic Activity: Economic and Social Factors, National Bureau of Economic Research Conference Series.

B. Black, W. Kim, H. Jang, 2006, “Does Corporate Governance Affect Firms' Market Values? Evidence from Korea,” Journal of Law, Economics, \& Organization.

Margaret M. Blair and Lynn A. Stout. 2001. "Trust, Trustworthiness, and the Behavioral Foundations of Corporate Law," 149 University of Pennsylvania Law Review: 17351810.

L. Beny, 2008, "Do Investors in Controlled Firms Value Insider Trading Laws? International Evidence," Journal of Law, Economics \& Policy (Symposium on Insider Trading) (forthcoming).

, 2007a, "Insider Trading Laws and Stock Markets Around the World: An Empirical Contribution to the Theoretical Law and Economics Debate," Journal of Corporation Law 32, 237-300.

, 2007b, "What Explains Insider Trading Restrictions Around the World? International Evidence on the Political Economy of Insider Trading Regulation," University of Michigan Law School Working Paper.

, 2005, “Do Insider Trading Laws Matter?” American Law and Economics Review 7, 144-183.

J. Bettis, J. Coles, and M. Lemmon, 2000, “Corporate Policies Restricting Trading by Insiders," Journal of Financial Economics 57, 191-220.

U. Bhattacharya and H. Daouk, 2002, “The World Price of Insider Trading,” Journal of Finance 57, 75-108.

U. Bhattacharya, H. Daouk, B. Jorgenson, and C. Kehr, 2000, "When an Event is Not an Event: The Curious Case of an Emerging Market," Journal of Financial Economics 55: 69-101.

A. Bhide, 1993, “The Hidden Costs of Stock Market Liquidity,” Journal of Financial Economics $34,31-51$.

A. Bris, 2005, “Do Insider Trading Laws Work?” European Financial Management 11, 267-312. 
V. Brudney, 1979, Insiders, Outsiders, and Informational Advantages Under the Federal Securities Laws, Harvard Law Review 93, 322-376.

R. Bushman, J. Piotroski, and A. Smith, 2005, Insider Trading Restrictions and Analysts' Incentives to Follow Firms, Journal of Finance 60, 35-66.

D. Carlton and D. Fischel, 1983, The Regulation of Insider Trading, Stanford Law Review 35, 857-895.

J.C. Coffee, 2002, "Racing Towards the Top?: The Impact of Cross-Listings and Stock Market Competition on International Corporate Governance," Columbia Law Review 102: 17571831.

J.W. Coles, V.B. McWilliams and N. Sen, 2000, “An Examination of the Relationship of Governance Mechanisms to Performance," Journal of Management 27: 23-50.

Copeland, Thomas E. and Dan Galai. 1983. Information Effects on the Bid-Ask Spread, 38 Journal of Finance 1457-1469.

J. Cox, 1986, Insider Trading and Contracting: A Critical Response to the Chicago School, Duke Law Journal 1986, 628-659.

R. Daniels and E. Iacobucci, 1999, Some of the Causes and Consequences of Corporate Ownership in Canada, in R. Morck, ed., Concentrated Corporate Ownership.

R. J. Daniels and R. Morck, eds., 1995, Corporate Decision-Making in Canada, Vol. 5, University Of Calgary Press.

Bernard J. Davies, 1975, “Canadian and American Attitudes on Insider Trading”, The University of Toronto Law Journal 25, 215-235.

H. Demsetz, 1986, Corporate Control, Insider Trading, and Rates of Return, American Economic Review 76, 313-316.

C. Doidge, A. Karolyi, and R. Stultz (2004), "Why are Foreign Firms that are Listed in the U.S. Worth More? 71 Journal of Financial Economics: 205-238.

, 2004, "Why do countries matter so much for corporate governance?” European Corporate Governance Institute Finance Working Paper No. 50/2004.

Michael P. Dooley, 1980. "Enforcement of Insider Trading Restrictions," 66 Virginia Law Review 1-89.

A. Durnev and E.H. Kim, 2005. "To Steal or Not to Steal: Firm Attributes, Legal Environment, and Valuation", Journal of Finance 60 (3) 1461 - 1493. 
Durnev, Artyom, Randall Morck, Bernard Yeung, and Paul Zarowin. 2003. Does Greater FirmSpecific Return Variation Mean More or Less Informed Stock Pricing? 41 Journal of Accounting Research: 797.

Art Durnev and Amrita Nain, 2007, Does Insider Trading Regulation Deter Private Information Trading? International Evidence, Pacific-Basin Finance Journal, Forthcoming

F. Easterbrook, 1985, Insider Trading as an Agency Problem, in J. Pratt and R. Zeckhauser, eds., Principles and Agents: The Structure of Business.

R. Epstein, 2004, In Defence of the Corporation, New Zealand Law Review 2004, 707-721.

Nuno Fernandes and Miguel A. Ferreira, 2007. "Insider Trading Laws and Stock Price Informativeness,” ECGI Working Paper Series in Finance, Working Paper No. 161/2007.

M. Fox et al., 2003, "Law, Share Price Accuracy, and Economic Performance: The New Evidence,” Michigan Law Review 102: 331-[ ].

Glaeser, Edward, Simon Johnson, and Andrei Shleifer. 2001. "Coase versus the Coasians," 116 Quarterly Journal of Economics 853-899.

The Globe and Mail. 2001. "When Insiders go Bad," 23 October.

Glosten, Lawrence R. and Lawrence E. Harris. 1988. "Estimating the Components of the Bid/Ask Spread," 21 Journal of Financial Economics 123-142.

D. Haddock and Jonathan R. Macey, 1997, A Coasian Model of Insider Trading, Northwestern University Law Review 80, 1449-1472.

H.E. Jackson, 2005, "Variation in the Intensity of Financial Regulation: Preliminary Evidence and Potential Implications," Harvard Olin Working Paper No. 521.

H.E. Jackson, 2006, "Regulatory Intensity in the Regulation of Capital Markets: A preliminary Comparison of Canadian and U.S. Approaches" research study prepared for the Investment Dealers' Association of Canada Task Force to Modernize Securities Legislation in Canada, online http://www.tfmsl.ca/docs/V6(2)\%20Jackson.pdf.R.

Insider Trading Task Force, 2003, Illegal Insider Trading in Canada: Recommendations on Prevention, Detention and Deterrence.

Alan D. Jagolinzer and Darren T. Roulstone, 2007, Litigation Risk and the Timing of Insiders' Trades around Earnings Announcements, Unpublished Working Paper.

Jack Johnston and John DiNardo, 1997, Econometric Methods. 
Adriana Korczak and M. Ameziane Lasfer. 2006. Does Cross-Listing Mitigate Insider Trading? Unpublished Working Paper.

Kraakman, 1991, The Legal Theory of Insider Trading Regulation in the United States, in European Insider Dealing (K. Hopt \& E. Wymeersch, eds): 39-55.

Patricia C. O’Brien and Ravi Bhushan. 1990. Analyst Following and Institutional Ownership, 28 Journal of Accounting Research: 55-76.

R. La Porta, F. Lopez-de-Silanes, A. Shleifer, and R. Vishny, 1998, Law and Finance, Journal of Political Economy 106, 1113-1153.

J. Macey, 1991, Insider Trading: Economics, Politics, and Policy.

H. Manne, 1966, Insider Trading and the Stock Market.

E. Maug, 2002, Insider Trading Legislation and Corporate Governance, European Economic Review 46, 1569-1597.

E. Maug and A. Ackerman, 2006, Insider Trading Legislation and Acquisition Announcements: Do Laws Matter? Unpublished Working Paper.

W.J. McNally and B.F. Smith, 2003, “Do Insiders Play by the Rules?” Vol. xxix, No. 2 Canadian Public Policy 125.

R. Morck, B. Yeung, and W. Yu, 2000, "Stock Markets: Why Do Emerging Markets Have Synchronous Stock Price Movements?” Journal of Financial Economics 58: 215-260.

W. A. Reese and M. S. Weisbach, 2002, "Protection of Minority Shareholder Interests, CrossListings in the United States, and Subsequent Equity Offerings", Journal of Financial Economics 66: 65-104.

R. Roll, 1988, "R²," Journal of Finance 43: 541-566.

Roberta Romano, 2001. "The Need for Competition in International Securities Regulation," 2 Theoretical Inquiries in Law: 1-178.

D.T. Roulstone, 2003, "The Relation between Insider-Trading Restrictions and Executive Compensation," Journal of Accounting Research 41: 525-551.

R. Schotland, 1967, "Unsafe at Any Price: A Reply to Manne, Insider Trading and the Stock Market," Virginia Law Review 53, 1425-1478.

Wise Person's Committee to Review the Structure of Securities Regulation in Canada. 2003. 


\title{
Table 1: Summary of Hypotheses
}

\author{
Hypothesis \\ Summary \\ Hypothesis Larger firms are more likely to have a compliant or super-compliant ITP than \\ 1 \\ smaller firms \\ Hypothesis Firms with higher market-to-book ratios are more likely to have a compliant or \\ super-compliant ITP than firms with lower market-to-book ratios \\ Hypothesis Firms with more concentrated ownership/control are more likely to have a \\ 3 \\ compliant or super-compliant ITP than firms with less concentrated \\ ownership/control \\ Hypothesis Firms with more firm-specific volatility of stock returns are more likely to have a \\ 4 \\ compliant or super-compliant ITP than firms with lower firm-specific volatility of \\ stock returns
}

Hypothesis Firms that are cross-listed in the U.S. are more likely to have a compliant or 5 super-compliant ITP than firms that are not cross-listed in the U.S. 


\title{
Table 2: Description of Variables
}

\author{
Variable \\ Description \\ Variables Related to Insider Trading Policies \\ ITP \\ This variable equals 1 if the company has an ITP that is publicly available, i.e., the company's ITP appears or \\ is mentioned in any paper or web-based document published on the company's website or SEDAR, and 0 \\ otherwise. \\ Source: SEDAR and firms' websites. \\ Format This variable equals 1 if the company's ITP is a standalone document; 2 if the company's ITP is embedded in \\ code of conduct or other document or there is a description of the policy in such a document; 3 if brief \\ reference is made to the company's ITP but no actual ITP is available; and 4 if other or not applicable. \\ Source: SEDAR and firms' websites. \\ Stringent This variable equals 1 if the company's ITP is stricter than existing insider trading law, i.e., the company's \\ ITP stipulates a blackout period(s), requires the appointment of an internal trading officer or monitor, or \\ requires application to trade during the blackout period(s). Conversely, this variable equals 0 if the \\ company's ITP is as strict as existing insider trading law, i.e., the company's ITP merely contains a \\ prohibition on trading while in possession of material nonpublic information). \\ Source: SEDAR and firms' websites. \\ Private Penalty This variable equals 1 if the company's ITP provides that the company will levy its own penalty in the event \\ of breach of the ITP or insider trading laws, and 0 otherwise. \\ Source: SEDAR and firms' websites.

\section{Firm-Specific Characteristics} \\ Stock Market \\ Capitalization \\ Sales Revenue \\ Assets \\ Market-to-Book \\ Ratio \\ Number of \\ Controlling \\ Shareholders \\ Total Voting \\ Control \\ This variable is the company's stock market capitalization, the closing stock price multiplied by the number \\ of outstanding shares in 2005 . It is a measure of the firm's size. \\ Source: Standard \& Poor's Compustat. \\ This variable is the company's net sales in 2005. It is a second measure of the firm's size. \\ Source: Standard \& Poor's Compustat. \\ This variable is the company's total assets in 2005. It is a third measure of firm size. \\ Source: Standard \& Poor's Compustat. \\ This variable is the ratio of the company's market value (common shares outstanding multiplied by the stock \\ price) to its book value of equity in 2005 . \\ Source: Standard \& Poor's Compustat. \\ This variable is the number of shareholders who owned more than $10 \%$ of the firm's voting shares in 2005 . \\ Source: SEDAR. \\ This variable is the total percent of voting shares owned by all of the company's controlling shareholders in \\ 2005.
}

Source: SEDAR. 
Average Voting This variable is the average percent of voting shares owned by each of the company's controlling Control shareholders in 2005.

Source: SEDAR.

Cross-Listed in the U.S.

Total Volatility of Stock Returns

Firm-Specific Volatility of Stock Returns

Industry Codes
This variable equals 1 if the company's shares were cross-listed on a U.S. exchange in 2005, and 0 otherwise.

Source: SEDAR, Standard \& Poor's Compustat and firms' websites.

This variable equals the standard deviation of monthly stock returns between 2002 and the end of 2005 . We calculate monthly stock returns using the closing stock price at the end of each month between January 2002 and December 31, 2005. Closing stock prices are adjusted for dividends and stock splits.

Source: monthly stock prices come from Standard \& Poors Compustat. In a few cases, we supplemented these data with monthly stock prices from Datastream or Yahoo.com.

This variable equals one minus the adjusted $\mathrm{R}^{2}$ from the market model of stock returns. It measures the variation in a firm's monthly returns that cannot be explained by general changes in the market.

Source: monthly stock prices come from Standard \& Poors Compustat. In a few cases, we supplemented these data with monthly stock prices from Datastream or Yahoo.com.

These categorical variables are the North American Industrial Classification System (NAICS) 3-digit industry codes.

Source: Standard and Poor's Compustat. 
Table 3: Prevalence of ITPs

\begin{tabular}{ccc}
\hline ITP & No ITP & Total \\
\hline 144 & 37 & 181 \\
\hline $79.56 \%$ & $20.44 \%$ & $100 \%$ \\
\hline
\end{tabular}

Table 4: Where do ITPs Publicly Appear?

This table is based on information from 143 firms that have ITPs, as we were unable to determine the location of the ITP for one firm out of the 144 firms that have an ITP. The percentages expressed in the table are rounded figures.

\begin{tabular}{lcc}
\hline Type & Number & Percent \\
\hline Standalone ITP & 26 & $18 \%$ \\
$\begin{array}{l}\text { Code of } \\
\text { Conduct or } \\
\text { other Document }\end{array}$ & 43 & $30 \%$ \\
$\begin{array}{l}\text { Only Reference } \\
\text { to ITP }\end{array}$ & 70 & \\
Other & 4 & $49 \%$ \\
\hline Total & 143 & $100 \%{ }^{*}$ \\
\hline
\end{tabular}


Table 5: Cross-Tabulation of ITP Stringency and Private Penalty Among Firms with ITPs

\begin{tabular}{|c|c|c|c|}
\hline & $\begin{array}{l}\text { Firm does not } \\
\text { have Private } \\
\text { Penalty }\end{array}$ & $\begin{array}{l}\text { Firm has } \\
\text { Private } \\
\text { Penalty }\end{array}$ & Total Number of Firms \\
\hline $\begin{array}{c}\text { ITP Equally as } \\
\text { Strict as } \\
\text { Canadian Law } \\
\text { (Stringent } \\
\text { equals } 0)\end{array}$ & $\begin{array}{c}17 \\
(12 \%)\end{array}$ & $\begin{array}{c}58 \\
(40 \%)\end{array}$ & $\begin{array}{c}75 \\
(52 \% \text { of the firms that have an ITP) }\end{array}$ \\
\hline $\begin{array}{c}\text { ITP More } \\
\text { Strict than } \\
\text { Canadian Law } \\
\text { (Stringent } \\
\text { equals } 1 \text { ) }\end{array}$ & $\begin{array}{c}13 \\
(9 \%)\end{array}$ & $\begin{array}{c}50 \\
(35 \%)\end{array}$ & (44\% of the firms that have an ITP) \\
\hline $\begin{array}{c}\text { Total Number } \\
\text { of Firms }\end{array}$ & $\begin{array}{c}30 \\
(21 \%)\end{array}$ & $\begin{array}{c}108 \\
(75 \%)\end{array}$ & $\begin{array}{c}138 \\
(96 \% \text { of the firms that have an ITP) }\end{array}$ \\
\hline
\end{tabular}


Table 6: Summary Statistics for Explanatory Variables

All variables are described in Table 2.

\begin{tabular}{|c|c|c|c|}
\hline Characteristic & $\begin{array}{c}\text { Number of } \\
\text { Observations }\end{array}$ & Mean & $\begin{array}{l}\text { Standard } \\
\text { Deviation }\end{array}$ \\
\hline Market Capitalization (millions) & 181 & $\$ 4,900$ & $\$ 7,720$ \\
\hline Net Sales (millions) & 179 & $\$ 3,696.64$ & $\$ 5,785.19$ \\
\hline Total Assets (millions) & 179 & $\$ 5,444.37$ & $\$ 10,881.06$ \\
\hline Market-to-Book Ratio & 168 & 3.31 & 2.81 \\
\hline $\begin{array}{l}\text { Firm has a Controlling Shareholder } \\
\text { ( } 10 \% \text { or more votes })(0 \text { or } 1)\end{array}$ & 181 & 0.67 & 0.47 \\
\hline Number of Controlling Shareholders & 176 & 0.95 & 0.95 \\
\hline $\begin{array}{l}\text { Total Percent of Votes Owned by } \\
\text { Controlling Shareholders }\end{array}$ & 113 & 41.01 & 27.22 \\
\hline $\begin{array}{l}\text { Average Percent of Votes Owned } \\
\text { per Controlling Shareholder }\end{array}$ & 113 & 32.35 & 25.40 \\
\hline $\begin{array}{l}\text { Total Volatility of Returns (Standard } \\
\text { Deviation of Monthly Returns (\%)) }\end{array}$ & 170 & 13.06 & 6.76 \\
\hline $\begin{array}{l}\text { Firm-Specific Volatility of Returns } \\
\text { (1- adjusted } \mathrm{R}^{2} \text { from Market Model } \\
\text { Regression) }\end{array}$ & 167 & 0.92 & 0.13 \\
\hline Cross-listed in the U.S. ( 0 or 1$)$ & 174 & 0.49 & 0.50 \\
\hline
\end{tabular}


Table 7: Differences in Means

Panel A: Characteristics of Firms with and without ITPs

The superscripts $\mathrm{a}, \mathrm{b}$ and $\mathrm{c}$ denote statistical significance at the $1 \%, 5 \%$ and $10 \%$ levels, respectively. All variables are described in Table 2.

\begin{tabular}{|c|c|c|c|}
\hline Characteristic & $\begin{array}{c}\text { No ITP } \\
(\text { ITP equals } 0) \\
(\mathrm{n}=37)\end{array}$ & $\begin{array}{c}\text { ITP } \\
(\text { ITP equals } 1) \\
(\mathrm{n}=144)\end{array}$ & $\begin{array}{c}\text { t-statistic } \\
\text { (difference in means) }\end{array}$ \\
\hline $\begin{array}{l}\text { Market Capitalization } \\
\text { (millions) }\end{array}$ & $\begin{array}{l}\$ 1,590 \\
(\mathrm{n}=37)\end{array}$ & $\begin{array}{c}\$ 5,750 \\
(\mathrm{n}=144)\end{array}$ & $2.98^{\mathrm{a}}$ \\
\hline Net Sales (millions) & $\begin{array}{l}\$ 1,191.1 \\
(\mathrm{n}=37)\end{array}$ & $\begin{array}{l}\$ 4,349.5 \\
(\mathrm{n}=142)\end{array}$ & $3.02^{\mathrm{a}}$ \\
\hline Total Assets (millions) & $\begin{array}{l}\$ 1,412.8 \\
(\mathrm{n}=37)\end{array}$ & $\begin{array}{l}\$ 6,494.8 \\
(\mathrm{n}=142)\end{array}$ & $2.57^{\mathrm{a}}$ \\
\hline Market-to-Book Ratio & $\begin{array}{c}3.9 \\
(\mathrm{n}=32)\end{array}$ & $\begin{array}{c}3.2 \\
(\mathrm{n}=136)\end{array}$ & 1.29 \\
\hline $\begin{array}{l}\text { Firm has a Controlling } \\
\text { Shareholder }(0 \text { or } 1) \\
(>=10 \% \text { votes })\end{array}$ & $\begin{array}{c}68 \% \\
(\mathrm{n}=37)\end{array}$ & $\begin{array}{c}67 \% \\
(n=144)\end{array}$ & 0.10 \\
\hline $\begin{array}{l}\text { Number of Controlling } \\
\text { Shareholders }\end{array}$ & $\begin{array}{c}0.75 \\
(\mathrm{n}=36)\end{array}$ & $\begin{array}{c}1.0 \\
(\mathrm{n}=140)\end{array}$ & 1.42 \\
\hline $\begin{array}{l}\text { Total Percent of Votes } \\
\text { Owned by Controlling } \\
\text { Shareholders }\end{array}$ & $\begin{array}{l}31.5 \% \\
(\mathrm{n}=24)\end{array}$ & $\begin{array}{c}43.6 \% \\
(n=89)\end{array}$ & $1.95^{\mathrm{b}}$ \\
\hline $\begin{array}{l}\text { Average Percent of } \\
\text { Votes Owned per } \\
\text { Controlling Shareholder }\end{array}$ & $\begin{array}{l}29.0 \% \\
(\mathrm{n}=24)\end{array}$ & $\begin{array}{c}33.2 \% \\
(\mathrm{n}=89)\end{array}$ & 0.72 \\
\hline $\begin{array}{l}\text { Total Volatility of } \\
\text { Returns (Standard } \\
\text { Deviation of Monthly } \\
\text { Returns) }\end{array}$ & $\begin{array}{l}15.12 \% \\
(\mathrm{n}=33)\end{array}$ & $\begin{array}{c}12.56 \% \\
(\mathrm{n}=137)\end{array}$ & $1.97^{\mathrm{b}}$ \\
\hline $\begin{array}{l}\text { Firm-Specific Volatility } \\
\text { of Returns } \\
\text { (1- adjusted } R^{2} \text { from } \\
\text { Market Model } \\
\text { Regression) }\end{array}$ & $\begin{array}{c}92 \% \\
(\mathrm{n}=32)\end{array}$ & $\begin{array}{c}92 \% \\
(n=135)\end{array}$ & 0.30 \\
\hline Cross-listed in the U.S. & $\begin{array}{c}39 \% \\
(n=33)\end{array}$ & $\begin{array}{c}51 \% \\
(\mathrm{n}=141)\end{array}$ & 1.21 \\
\hline
\end{tabular}


Table 7: Differences in Means

Panel B: Characteristics of Firms by Strictness of ITP

All variables are described in Table 2.

\begin{tabular}{|c|c|c|c|}
\hline Characteristic & $\begin{array}{c}\text { Equally Strict } \\
\text { as Law } \\
\text { (Stringent } \\
\text { equals 0) } \\
(\mathrm{n}=75)\end{array}$ & $\begin{array}{c}\text { Stricter Than } \\
\text { Law } \\
\text { (Stringent } \\
\text { equals 1) } \\
(\mathrm{n}=63)\end{array}$ & $\begin{array}{c}\text { t-statistic } \\
\text { (difference in means) }\end{array}$ \\
\hline $\begin{array}{l}\text { Market Capitalization } \\
\text { (millions) }\end{array}$ & $\begin{array}{l}\$ 5,790 \\
(n=75)\end{array}$ & $\begin{array}{l}\$ 5,920 \\
(n=63)\end{array}$ & 0.09 \\
\hline Net Sales (millions) & $\begin{array}{l}\$ 4,691.0 \\
(\mathrm{n}=75)\end{array}$ & $\begin{array}{l}\$ 4,033.9 \\
(\mathrm{n}=62)\end{array}$ & 0.61 \\
\hline Total Assets (millions) & $\begin{array}{l}\$ 7,759.6 \\
(\mathrm{n}=75)\end{array}$ & $\begin{array}{l}\$ 5,309.6 \\
(n=62)\end{array}$ & 1.18 \\
\hline Market-to-Book Ratio & $\begin{array}{c}3.08 \\
(n=72)\end{array}$ & $\begin{array}{c}3.13 \\
(n=59)\end{array}$ & 0.13 \\
\hline $\begin{array}{l}\text { Firm has a Controlling } \\
\text { Shareholder }(0 \text { or } 1) \\
(>=10 \% \text { votes })\end{array}$ & $\begin{array}{c}60 \% \\
(n=75)\end{array}$ & $\begin{array}{c}75 \% \\
(n=63)\end{array}$ & $1.82^{\mathrm{c}}$ \\
\hline $\begin{array}{l}\text { Number of Controlling } \\
\text { Shareholders }\end{array}$ & $\begin{array}{c}0.79 \\
(n=75)\end{array}$ & $\begin{array}{c}1.30 \\
(n=60)\end{array}$ & $2.98^{\mathrm{a}}$ \\
\hline $\begin{array}{l}\text { Total Percent of Votes } \\
\text { Owned by Controlling } \\
\text { Shareholders }\end{array}$ & $\begin{array}{c}43.5 \% \\
(n=43)\end{array}$ & $\begin{array}{c}43.0 \% \\
(n=43)\end{array}$ & 0.09 \\
\hline $\begin{array}{l}\text { Average Percent of } \\
\text { Votes Owned per } \\
\text { Controlling Shareholder }\end{array}$ & $\begin{array}{l}37.0 \% \\
(n=43)\end{array}$ & $\begin{array}{l}28.1 \% \\
(n=43)\end{array}$ & $1.63^{*}$ \\
\hline $\begin{array}{l}\text { Total Volatility of } \\
\text { Returns (Standard } \\
\text { Deviation of Monthly } \\
\text { Returns) }\end{array}$ & $\begin{array}{l}12.4 \% \\
(n=69)\end{array}$ & $\begin{array}{l}12.3 \% \\
(n=61)\end{array}$ & 0.10 \\
\hline $\begin{array}{l}\text { Firm-Specific Volatility } \\
\text { of Returns } \\
\text { (1- adjusted } \mathrm{R}^{2} \text { from } \\
\text { Market Model } \\
\text { Regression) }\end{array}$ & $\begin{array}{c}90 \% \\
(n=67)\end{array}$ & $\begin{array}{c}93 \% \\
(n=61)\end{array}$ & $1.52^{* *}$ \\
\hline Cross-listed in the U.S. & $\begin{array}{c}47 \% \\
(n=74)\end{array}$ & $\begin{array}{c}58 \% \\
(n=62)\end{array}$ & 1.25 \\
\hline Private Penalty & $\begin{array}{c}79 \% \\
(n=75)\end{array}$ & $\begin{array}{c}77 \% \\
(n=63)\end{array}$ & 0.29 \\
\hline
\end{tabular}

*The difference is significant at the $11 \%$ level.

$* *$ The difference is significant at the $15 \%$ level. 
Table 8: Bivariate Correlations

This table presents bivariate correlation coefficients. The numbers in parentheses are the probability levels ( $p$-values) at which the null hypothesis of zero

correlation can be rejected in two-tailed tests. The superscripts $a, b$, and c denote statistical significance at the $1 \%, 5 \%$ and $10 \%$ levels, respectively. All variables are described in Table 2.

\begin{tabular}{|c|c|c|c|c|c|c|c|c|c|c|c|c|c|c|}
\hline & ITP & $\begin{array}{c}\text { Stricter } \\
\text { than Law }\end{array}$ & $\begin{array}{l}\text { Private } \\
\text { Penalty }\end{array}$ & $\begin{array}{c}\text { Stock } \\
\text { Market } \\
\text { Cap. }\end{array}$ & $\begin{array}{c}\text { Net } \\
\text { Sales }\end{array}$ & $\begin{array}{c}\text { Total } \\
\text { Assets }\end{array}$ & $\begin{array}{c}\text { Market- } \\
\text { to-Book } \\
\text { Ratio }\end{array}$ & $\begin{array}{l}\text { Cont. } \\
\text { Sh'r. }\end{array}$ & $\begin{array}{l}\text { No. of } \\
\text { Cont. } \\
\text { Sh'rs }\end{array}$ & $\begin{array}{l}\text { \% Votes } \\
\text { of Cont. } \\
\text { Sh'rs }\end{array}$ & $\begin{array}{l}\text { Ave. } \% \\
\text { Votes Per } \\
\text { Contr. } \\
\text { Shr. } \\
\end{array}$ & $\begin{array}{c}\text { Firm- } \\
\text { Specific } \\
\text { Volatility }\end{array}$ & $\begin{array}{c}\text { Total } \\
\text { Volatility }\end{array}$ & $\begin{array}{l}\text { Cross- } \\
\text { Listed in } \\
\text { the U.S. }\end{array}$ \\
\hline ITP & 1.00 & & & & & & & & & & & & & \\
\hline Stricter than Law & $\begin{array}{c}0.08 \\
(0.36)\end{array}$ & 1.00 & & & & & & & & & & & & \\
\hline Private Penalty & $\begin{array}{c}-0.04 \\
(0.60) \\
\end{array}$ & $\begin{array}{c}0.02 \\
(0.78) \\
\end{array}$ & 1.00 & & & & & & & & & & & \\
\hline $\begin{array}{l}\text { Stock Market } \\
\text { Capitalization }\end{array}$ & $\begin{array}{r}0.22^{\mathrm{a}} \\
(0.00) \\
\end{array}$ & $\begin{array}{c}0.01 \\
(0.93) \\
\end{array}$ & $\begin{array}{l}-0.06 \\
(0.51) \\
\end{array}$ & 1.00 & & & & & & & & & & \\
\hline Net Sales & $\begin{array}{c}0.22^{\mathrm{a}} \\
(0.00)\end{array}$ & $\begin{array}{l}-0.05 \\
(0.54)\end{array}$ & $\begin{array}{l}-0.03 \\
(0.74)\end{array}$ & $\begin{array}{c}0.64^{\mathrm{a}} \\
(0.00)\end{array}$ & 1.00 & & & & & & & & & \\
\hline Total Assets & $\begin{array}{l}0.19^{\mathrm{a}} \\
(0.01)\end{array}$ & $\begin{array}{l}-0.10 \\
(0.24)\end{array}$ & $\begin{array}{c}0.00 \\
(0.97)\end{array}$ & $\begin{array}{c}0.60^{\mathrm{a}} \\
(0.00)\end{array}$ & $\begin{array}{c}0.70^{\mathrm{a}} \\
(0.00)\end{array}$ & 1.00 & & & & & & & & \\
\hline $\begin{array}{l}\text { Market-to-Book } \\
\text { Ratio }\end{array}$ & $\begin{array}{l}-0.10 \\
(0.20)\end{array}$ & $\begin{array}{c}0.01 \\
(0.90)\end{array}$ & $\begin{array}{c}0.13 \\
(0.14)\end{array}$ & $\begin{array}{c}0.08 \\
(0.31)\end{array}$ & $\begin{array}{l}-0.09 \\
(0.23)\end{array}$ & $\begin{array}{l}-0.07 \\
(0.40)\end{array}$ & 1.00 & & & & & & & \\
\hline $\begin{array}{l}\text { Firm has a } \\
\text { Controlling } \\
\text { Shareholder }\end{array}$ & $\begin{array}{l}-0.01 \\
(0.92)\end{array}$ & $\begin{array}{l}0.15^{\mathrm{c}} \\
(0.07)\end{array}$ & $\begin{array}{l}-0.04 \\
(0.61)\end{array}$ & $\begin{array}{l}-0.17^{b} \\
(0.03)\end{array}$ & $\begin{array}{c}0.04 \\
(0.60)\end{array}$ & $\begin{array}{l}-0.07 \\
(0.38)\end{array}$ & $\begin{array}{l}-0.13^{\mathrm{c}} \\
(0.09)\end{array}$ & 1.00 & & & & & & \\
\hline $\begin{array}{l}\text { Number of } \\
\text { Controlling } \\
\text { Shareholders }\end{array}$ & $\begin{array}{c}0.11 \\
(0.16)\end{array}$ & $\begin{array}{l}0.25^{\mathrm{a}} \\
(0.00)\end{array}$ & $\begin{array}{c}0.04 \\
(0.66)\end{array}$ & $\begin{array}{l}-0.16^{b} \\
(0.03)\end{array}$ & $\begin{array}{c}0.01 \\
(0.86)\end{array}$ & $\begin{array}{l}-0.09 \\
(0.26)\end{array}$ & $\begin{array}{l}-0.20^{\mathrm{a}} \\
(0.01)\end{array}$ & $\begin{array}{l}0.72^{\mathrm{a}} \\
(0.00)\end{array}$ & 1.00 & & & & & \\
\hline $\begin{array}{l}\text { \% Votes } \\
\text { Owned } \\
\text { by Controlling } \\
\text { Shareholders }\end{array}$ & $\begin{array}{l}0.18^{\mathrm{b}} \\
(0.05)\end{array}$ & $\begin{array}{l}-0.01 \\
(0.93)\end{array}$ & $\begin{array}{c}0.08 \\
(0.43)\end{array}$ & $\begin{array}{c}0.22^{\mathrm{b}} \\
(0.02)\end{array}$ & $\begin{array}{r}0.35^{\mathrm{a}} \\
(0.00)\end{array}$ & $\begin{array}{c}0.23^{\mathrm{a}} \\
(0.01)\end{array}$ & $\begin{array}{l}-0.24^{b} \\
(0.02)\end{array}$ & $(0.00)$ & $\begin{array}{c}0.32^{\mathrm{a}} \\
(0.00)\end{array}$ & 1.00 & & & & \\
\hline Average & 0.07 & -0.18 & -0.01 & $0.29^{\mathrm{a}}$ & $0.41^{\mathrm{a}}$ & $0.30^{\mathrm{a}}$ & -0.11 & & $-0.28^{\mathrm{a}}$ & $0.81^{\mathrm{a}}$ & & & & \\
\hline
\end{tabular}




\begin{tabular}{|c|c|c|c|c|c|c|c|c|c|c|c|c|c|c|}
\hline $\begin{array}{l}\text { \% Votes } \\
\text { per Controlling } \\
\text { Shareholder }\end{array}$ & $(0.47)$ & $(0.11)$ & $(0.93)$ & $(0.00)$ & $(0.00)$ & $(0.00)$ & $(0.25)$ & $(0.00)$ & $(0.00)$ & $(0.00)$ & 1.00 & & & \\
\hline $\begin{array}{l}\text { Firm-Specific } \\
\text { Volatility of Returns }\end{array}$ & $\begin{array}{l}-0.02 \\
(0.76)\end{array}$ & $\begin{array}{c}0.13 \\
(0.13)\end{array}$ & $\begin{array}{l}-0.03 \\
(0.77)\end{array}$ & $\begin{array}{c}0.07 \\
(0.37)\end{array}$ & $\begin{array}{l}-0.04 \\
(0.58)\end{array}$ & $\begin{array}{l}-0.02 \\
(0.84)\end{array}$ & $\begin{array}{c}0.09 \\
(0.26)\end{array}$ & $\begin{array}{l}-0.04 \\
(0.64)\end{array}$ & $\begin{array}{l}-0.04 \\
(0.62)\end{array}$ & $\begin{array}{l}-0.20^{\mathrm{b}} \\
(0.04)\end{array}$ & $\begin{array}{l}-0.21^{b} \\
(0.04)\end{array}$ & 1.00 & & \\
\hline $\begin{array}{l}\text { Total Volatility of } \\
\text { Returns }\end{array}$ & $\begin{array}{l}-0.15^{\mathrm{b}} \\
(0.05) \\
\end{array}$ & $\begin{array}{l}-0.01 \\
(0.92) \\
\end{array}$ & $\begin{array}{c}0.01 \\
(0.89) \\
\end{array}$ & $\begin{array}{l}-0.02 \\
(0.82) \\
\end{array}$ & $\begin{array}{l}-0.16^{\mathrm{b}} \\
(0.03) \\
\end{array}$ & $\begin{array}{l}-0.07 \\
(0.38) \\
\end{array}$ & $\begin{array}{r}0.29^{\mathrm{a}} \\
(0.00) \\
\end{array}$ & $\begin{array}{l}-0.21^{\mathrm{a}} \\
(0.01)\end{array}$ & $\begin{array}{l}-0.19^{\mathrm{a}} \\
(0.01)\end{array}$ & $\begin{array}{l}-0.12 \\
(0.24) \\
\end{array}$ & $\begin{array}{l}-0.07 \\
(0.47) \\
\end{array}$ & $\begin{array}{r}0.07 \\
(0.35) \\
\end{array}$ & 1.00 & \\
\hline $\begin{array}{l}\text { Cross-Listed in the } \\
\text { U.S. }\end{array}$ & $\begin{array}{c}0.09 \\
(0.23)\end{array}$ & $\begin{array}{c}0.11 \\
(0.21)\end{array}$ & $\begin{array}{l}-0.01 \\
(0.95)\end{array}$ & $\begin{array}{c}0.22^{\mathrm{a}} \\
(0.00)\end{array}$ & $\begin{array}{c}0.03 \\
(0.68)\end{array}$ & $\begin{array}{c}0.08 \\
(0.28)\end{array}$ & $\begin{array}{l}-0.02 \\
(0.78)\end{array}$ & $\begin{array}{l}-0.17^{b} \\
(0.02)\end{array}$ & $\begin{array}{l}-0.15^{b} \\
(0.04)\end{array}$ & $\begin{array}{l}-0.08 \\
(0.43)\end{array}$ & $\begin{array}{c}0.00 \\
(0.98)\end{array}$ & $\begin{array}{l}-0.24^{\mathrm{a}} \\
(0.00)\end{array}$ & $\begin{array}{c}0.02 \\
(0.81)\end{array}$ & 1.00 \\
\hline
\end{tabular}


Table 9: Probit Regressions

\section{Panel A: Determinants of Having an ITP}

This table presents probit regressions on the determinants of ITPs. The dependent variable, ITP, equals 1 if the firm has an ITP, and 0 otherwise. The regressions in columns (1) through (3) do not control for industry, while the regressions in columns (4) through (6) do. Superscripts a, b, c denote statistical significance at the $1 \%, 5 \%$, and $10 \%$ levels, respectively. Robust standard errors are reported in parentheses. All variables are described in Table 2.

\begin{tabular}{|c|c|c|c|c|c|c|}
\hline Explanatory Variable & (1) & (2) & (3) & (4) & (5) & (6) \\
\hline $\begin{array}{l}\text { Log of Market Capitalization } \\
\text { (Hypothesis 1) }\end{array}$ & $\begin{array}{c}0.452^{\mathrm{a}} \\
(0.122)\end{array}$ & $\begin{array}{c}0.473^{\mathrm{a}} \\
(0.124)\end{array}$ & $\begin{array}{l}0.511^{\mathrm{a}} \\
(0.130)\end{array}$ & $\begin{array}{c}0.522^{\mathrm{a}} \\
(0.128)\end{array}$ & $\begin{array}{c}0.512^{\mathrm{a}} \\
(0.131)\end{array}$ & $\begin{array}{c}0.565^{\mathrm{a}} \\
(0.142)\end{array}$ \\
\hline $\begin{array}{l}\text { Market-to-Book Ratio } \\
\text { (Hypothesis 2) }\end{array}$ & $\begin{array}{l}-0.078^{b} \\
(0.038)\end{array}$ & $\begin{array}{l}-0.066^{\mathrm{C}} \\
(0.038)\end{array}$ & $\begin{array}{l}-0.067^{\mathrm{c}} \\
(0.040)\end{array}$ & $\begin{array}{l}-0.066^{\mathrm{C}} \\
(0.035)\end{array}$ & $\begin{array}{l}-0.057 \\
(0.035)\end{array}$ & $\begin{array}{c}-0.055 \\
(0.038)\end{array}$ \\
\hline $\begin{array}{l}\text { Firm has a Controlling } \\
\text { Shareholder }(0 \text { or } 1) \\
(>=10 \% \text { votes }) \\
\text { (Hypothesis } 3)\end{array}$ & $\begin{array}{c}0.245 \\
(0.264)\end{array}$ & & $\begin{array}{l}-1.177^{b} \\
(0.599)\end{array}$ & $\begin{array}{l}-0.010 \\
(0.282)\end{array}$ & & $\begin{array}{l}-1.547^{\mathrm{a}} \\
(0.623)\end{array}$ \\
\hline $\begin{array}{l}\text { Number of Controlling } \\
\text { Shareholders } \\
\text { (Hypothesis 3) }\end{array}$ & & $\begin{array}{c}0.389^{\mathrm{a}} \\
(0.143)\end{array}$ & $\begin{array}{c}1.158^{\mathrm{a}} \\
(0.476)\end{array}$ & & $\begin{array}{c}0.272^{b} \\
(0.141)\end{array}$ & $\begin{array}{c}1.256^{\mathrm{a}} \\
(0.491)\end{array}$ \\
\hline $\begin{array}{l}\text { Firm-Specific Volatility } \\
\text { (1-adjusted } \mathrm{R}^{2} \text { from Market } \\
\text { Model Regression) } \\
\text { (Hypothesis } 4)\end{array}$ & $\begin{array}{c}-0.150 \\
(1.046)\end{array}$ & $\begin{array}{c}-0.118 \\
(1.071)\end{array}$ & $\begin{array}{c}-0.223 \\
(1.048)\end{array}$ & $\begin{array}{c}0.570 \\
(1.111)\end{array}$ & $\begin{array}{c}0.592 \\
(1.134)\end{array}$ & $\begin{array}{c}0.638 \\
(1.134)\end{array}$ \\
\hline $\begin{array}{l}\text { Cross-listed in the U.S. } \\
\text { (Hypothesis 5) }\end{array}$ & $\begin{array}{c}0.088 \\
(0.268)\end{array}$ & $\begin{array}{c}0.152 \\
(0.275)\end{array}$ & $\begin{array}{c}0.125 \\
(0.278)\end{array}$ & $\begin{array}{c}0.117 \\
(0.290)\end{array}$ & $\begin{array}{c}0.170 \\
(0.294)\end{array}$ & $\begin{array}{c}0.121 \\
(0.309)\end{array}$ \\
\hline Constant & $\begin{array}{l}-8.460^{\mathrm{a}} \\
(2.836)\end{array}$ & $\begin{array}{l}-9.167^{\mathrm{a}} \\
(2.853)\end{array}$ & $\begin{array}{c}-9.697^{\mathrm{a}} \\
(2.97)\end{array}$ & $\begin{array}{c}-10.159^{\mathrm{a}} \\
(2.795)\end{array}$ & $\begin{array}{c}-10.356^{\mathrm{a}} \\
(2.822)\end{array}$ & $\begin{array}{c}-11.210^{\mathrm{a}} \\
(2.998)\end{array}$ \\
\hline Industry Dummies & No & No & No & Yes & Yes & Yes \\
\hline Number of Observations & 155 & 153 & 153 & 140 & 138 & 138 \\
\hline Pseudo $\mathrm{R}^{2}$ & 0.109 & 0.141 & 0.170 & 0.157 & 0.172 & 0.215 \\
\hline$\chi^{2}$ & 20.32 & 26.04 & 27.56 & 32.36 & 31.94 & 38.75 \\
\hline Prob $>\chi^{2}$ & 0.001 & 0.000 & 0.000 & 0.000 & 0.000 & 0.000 \\
\hline
\end{tabular}


Table 9: Probit Regressions

Panel B: Determinants of Having an ITP that is Stricter than Ontario Insider Trading Law

This table presents probit regressions on the determinants of ITP strictness. The dependent variable, Stringent, equals 1 if the ITP is stricter than Ontario insider trading law, and 0 otherwise. The regressions in columns (1) through (3) do not control for industry, while the regressions in columns (4) through (6) do. Superscripts a, b, and c denote statistical significance at the $1 \%, 5 \%$, and $10 \%$ levels, respectively. Robust standard errors are reported in parentheses. All variables are described in Table 2.

\begin{tabular}{|c|c|c|c|c|c|c|}
\hline Explanatory Variable & (1) & (2) & (3) & (4) & (5) & (6) \\
\hline $\begin{array}{l}\text { Log of Market Capitalization } \\
\text { (Hypothesis 1) }\end{array}$ & $\begin{array}{c}0.0624 \\
(0.100)\end{array}$ & $\begin{array}{c}0.086 \\
(0.104)\end{array}$ & $\begin{array}{c}0.087 \\
(0.104)\end{array}$ & $\begin{array}{c}0.066 \\
(0.109)\end{array}$ & $\begin{array}{c}0.073 \\
(0.113)\end{array}$ & $\begin{array}{c}0.073 \\
(0.113)\end{array}$ \\
\hline $\begin{array}{l}\text { Market-to-Book Ratio } \\
\text { (Hypothesis 2) }\end{array}$ & $\begin{array}{c}0.013 \\
(0.053)\end{array}$ & $\begin{array}{c}0.032 \\
(0.053)\end{array}$ & $\begin{array}{c}0.032 \\
(0.052)\end{array}$ & $\begin{array}{c}0.014 \\
(0.059)\end{array}$ & $\begin{array}{c}0.026 \\
(0.059)\end{array}$ & $\begin{array}{c}0.026 \\
(0.058)\end{array}$ \\
\hline $\begin{array}{l}\text { Firm has a Controlling } \\
\text { Shareholder }(0 \text { or } 1) \\
\text { ( }>=10 \% \text { votes }) \\
\text { (Hypothesis } 3)\end{array}$ & $\begin{array}{c}0.515^{\mathrm{b}} \\
(0.249)\end{array}$ & & $\begin{array}{c}-0.272 \\
(0.388)\end{array}$ & $\begin{array}{c}0.727^{\mathrm{a}} \\
(0.272)\end{array}$ & & $\begin{array}{c}-0.174 \\
(0.410)\end{array}$ \\
\hline $\begin{array}{l}\text { Number of Controlling } \\
\text { Shareholders } \\
\text { (Hypothesis 3) }\end{array}$ & & $\begin{array}{c}0.428^{\mathrm{a}} \\
(0.133)\end{array}$ & $\begin{array}{c}0.533^{\mathrm{a}} \\
(0.215)\end{array}$ & & $\begin{array}{c}0.555^{\mathrm{a}} \\
(0.148)\end{array}$ & $\begin{array}{c}0.628^{\mathrm{a}} \\
(0.223)\end{array}$ \\
\hline $\begin{array}{l}\text { Firm-Specific Volatility } \\
\text { (1- adjusted } \mathrm{R}^{2} \text { from Market } \\
\text { Model Regression) } \\
\text { (Hypothesis 4) }\end{array}$ & $\begin{array}{c}1.808^{\mathrm{c}} \\
(0.965)\end{array}$ & $\begin{array}{l}2.132^{b} \\
(0.978)\end{array}$ & $\begin{array}{c}2.168^{b} \\
(0.980)\end{array}$ & $\begin{array}{c}1.637 \\
(1.089)\end{array}$ & $\begin{array}{c}2.059^{\mathrm{c}} \\
(1.148)\end{array}$ & $\begin{array}{c}2.121^{\mathrm{c}} \\
(1.151)\end{array}$ \\
\hline $\begin{array}{l}\text { Cross-listed in the U.S. } \\
\text { (Hypothesis 5) }\end{array}$ & $\begin{array}{c}0.529^{b} \\
(0.252)\end{array}$ & $\begin{array}{c}0.655^{\mathrm{b}} \\
(0.269)\end{array}$ & $\begin{array}{c}0.644^{b} \\
(0.272)\end{array}$ & $\begin{array}{c}0.416^{\mathrm{b}} \\
(0.270)\end{array}$ & $\begin{array}{c}0.574^{b} \\
(0.291)\end{array}$ & $\begin{array}{c}0.572^{\mathrm{b}} \\
(0.293)\end{array}$ \\
\hline Constant & $\begin{array}{l}-3.733^{\mathrm{c}} \\
(2.247)\end{array}$ & $\begin{array}{l}-4.784^{b} \\
(2.303)\end{array}$ & $\begin{array}{l}-4.755^{b} \\
(2.314)\end{array}$ & $\begin{array}{l}-3.426 \\
(2.527)\end{array}$ & $\begin{array}{l}-4.301^{\mathrm{c}} \\
(2.569)\end{array}$ & $\begin{array}{l}-4.315^{\mathrm{c}} \\
(2.576)\end{array}$ \\
\hline Industry Dummies & No & No & No & Yes & Yes & Yes \\
\hline Number of Observations & 123 & 121 & 121 & 123 & 121 & 121 \\
\hline Pseudo $\mathrm{R}^{2}$ & 0.059 & 0.105 & 0.108 & 0.151 & 0.201 & 0.201 \\
\hline$\chi^{2}$ & 10.52 & 17.07 & 16.06 & 16.11 & 22.48 & 22.10 \\
\hline Prob $>\chi^{2}$ & 0.062 & 0.004 & 0.108 & 0.097 & 0.013 & 0.024 \\
\hline
\end{tabular}




\section{Table 10: Ordered Probit Regressions}

This table presents ordered probit regressions on the determinants of ITP strictness. In column (1), the dependent variable, Ordered_Stringency, equals 1 if the firm does not have an ITP $($ ITP $=0), 2$ if the firm has an ITP $(I T P=1)$ but no mechanism for imposing private sanctions (Private Penalty $=0), 3$ if the firm has an ITP $($ ITP $=1)$ and may impose private sanctions (Private Penalty $=1), 4$ if the firm's ITP is more restrictive than Canadian insider trading law $($ Stringent $=1)$ but the firm does not have a mechanism for imposing private sanctions (Private Penalty $=0)$, and 5 if the firm's ITP is more restrictive than Canadian insider trading law $($ Stringent $=1)$ and the firm may impose private sanctions (Private Penalty = 1). In column (2), the dependent variable is the same as in column (1) except that rankings 3 and 4 are reversed. Finally, in column (3), the dependent variable, Ordered_Formal, equals 1 if the firm does not have an ITP $(I T P=0), 2$ if the firm has an ITP that is just as strict as Canadian law $($ Stringent $=0)$, and 3 if the firm has an ITP that is stricter than Canadian law (Stringent $=1$ ). Superscripts a, b, and c denote statistical significance at the $1 \%, 5 \%$, and $10 \%$ levels, respectively. Robust standard errors are reported in parentheses. All variables are described in Table 2.

\begin{tabular}{|c|c|c|c|}
\hline $\begin{array}{l}\text { Explanatory } \\
\text { Variable }\end{array}$ & $\begin{array}{c}\mathbf{( 1 )} \\
\text { Original } \\
\text { Order }\end{array}$ & $\begin{array}{c}\text { (2) } \\
\text { Reordered }\end{array}$ & $\begin{array}{c}\text { (3) } \\
\text { Formal } \\
\text { Rules Only }\end{array}$ \\
\hline $\begin{array}{l}\text { Log of Market } \\
\text { Capitalization } \\
\text { (Hypothesis 1) }\end{array}$ & $\begin{array}{c}0.279^{\mathrm{a}} \\
(0.081)\end{array}$ & $\begin{array}{c}0.266^{\mathrm{a}} \\
(0.080)\end{array}$ & $\begin{array}{c}0.311^{\mathrm{a}} \\
(0.088)\end{array}$ \\
\hline $\begin{array}{l}\text { Market-to-Book } \\
\text { Ratio } \\
\text { (Hypothesis 2) }\end{array}$ & $\begin{array}{l}-0.020 \\
(0.032)\end{array}$ & $\begin{array}{l}-0.009 \\
(0.031)\end{array}$ & $\begin{array}{l}-0.036 \\
(0.034)\end{array}$ \\
\hline $\begin{array}{l}\text { Firm has a } \\
\text { Controlling } \\
\text { Shareholder } \\
(0 \text { or } 1) \\
(>=10 \% \text { votes) } \\
\text { (Hypothesis } 3)\end{array}$ & $\begin{array}{l}-0.699^{b} \\
(0.317)\end{array}$ & $\begin{array}{l}-0.812^{\mathrm{a}} \\
(0.313)\end{array}$ & $\begin{array}{l}-0.626^{\mathrm{c}} \\
(0.340)\end{array}$ \\
\hline $\begin{array}{l}\text { Number of } \\
\text { Controlling } \\
\text { Shareholders } \\
\text { (Hypothesis 3) }\end{array}$ & $\begin{array}{c}0.737^{\mathrm{a}} \\
(0.189)\end{array}$ & $\begin{array}{l}0.739^{\mathrm{a}} \\
(0.184)\end{array}$ & $\begin{array}{l}0.744^{\mathrm{a}} \\
(0.200)\end{array}$ \\
\hline $\begin{array}{l}\text { Firm-Specific } \\
\text { Volatility } \\
\text { (1- adjusted } \mathrm{R}^{2} \\
\text { from Market Model } \\
\text { Regression) } \\
\text { (Hypothesis 4) }\end{array}$ & $\begin{array}{l}1.214^{\mathrm{c}} \\
(0.746)\end{array}$ & $\begin{array}{c}0.824 \\
(0.722)\end{array}$ & $\begin{array}{c}1.36^{\mathrm{c}} \\
(0.789)\end{array}$ \\
\hline $\begin{array}{l}\text { Cross-listed in the } \\
\text { U.S. }\end{array}$ & $\begin{array}{c}0.357^{\mathrm{c}} \\
(0.208) \\
\end{array}$ & $\begin{array}{c}0.329^{*} \\
(0.206)\end{array}$ & $\begin{array}{c}0.382^{\mathrm{c}} \\
(0.218) \\
\end{array}$ \\
\hline
\end{tabular}




\begin{tabular}{|l|c|c|c|}
\hline$($ Hypothesis 5) & & & \\
\hline Industry Dummies & Yes & Yes & Yes \\
\hline $\begin{array}{l}\text { Number of } \\
\text { Observations }\end{array}$ & 148 & 148 & 148 \\
\hline Pseudo R & & 0.08 & 0.13 \\
\hline$\chi^{2}$ & 0.09 & 36.34 & 40.41 \\
\hline Prob $>\chi^{2}$ & 0.000 & 0.000 & 0.000 \\
\hline
\end{tabular}

*The coefficient is only significant at the $11 \%$ level. 


\title{
Appendix 1: Ontario and U.S. Insider Trading Laws
}

\author{
Ontario Insider Trading Law
}

\section{A. Insider Trading:}

Prohibited insider trading is contained in the s. 76(1) of the Ontario Securities Act. Legislation across Canadian provincial jurisdictions is consistent with this provision (see (ASA, s. 147(2); BCSA, s. 86(1); NfldSA, s. 77(1); and QSA s. 188).

s. 76(1): "No person or company in a special relationship with a reporting issuer shall purchase or sell securities of the reporting issuer with the knowledge of a material fact or material change with respect to the reporting issuer that has not been generally disclosed."

Note that the provision applies to anyone in a special relationship with the issuer (as noted previously, not simply insiders as defined in the statute) who have bought or sold the issuer's securities. Furthermore, the knowledge must consist of a material fact or a material change and the information cannot have been generally disclosed already. If these elements are present, then the legislation has been breached. To be sure, the elements are as follows: (i) special relationship; (ii) knowledge of a material fact or change; (iii) not generally disclosed.

\section{Special Relationship}

Thus, the definition of special relationship is of crucial importance. In particular, if there is a claim against $x$ for illegal insider trading, then $x$ must have been in a special relationship with the issuer. This means that $\mathrm{x}$ must be (in the words of the statutory definition):

s. $76(5)$

(a) a person or company that is an insider, affiliate or associate of,

(i) the reporting issuer,

(ii) a person or company that is proposing to make a take-over bid, as defined in

Part XX, for the securities of the reporting issuer, or

(iii) a person or company that is proposing to become a party to a reorganization, amalgamation, merger or arrangement or similar business combination with the reporting issuer or to acquire a substantial portion of its property,

(b) a person or company that is engaging in or proposes to engage in any business or professional activity with or on behalf of the reporting issuer or with or on behalf of a person or company described in subclause (a) (ii) or (iii), (c) a person who is a director, officer or employee of the reporting issuer or of a person or company described in subclause (a) (ii) or (iii) or clause (b),

(d) a person or company that learned of the material fact or material change with respect to the reporting issuer while the person or company was a person or company described in clause (a), (b) or (c),

(e) a person or company that learns of a material fact or material change with respect to the issuer from any other person or company described in this

subsection, including a person or company described in this clause, and knows or 
ought reasonably to have known that the other person or company is a person or company in such a relationship. (OSA, s. 76 (5); ASA, s. 9; BCSA, s. 3; Nfld, s. 77(5); QSA, s. 189)

Without doubt, the definition is broad. People in a special relationship are not only insiders but also parties making a takeover bid or engaged in some other proposed transaction with the issuer (See subsection (a)(ii) and (iii)). Directors, officers and employees are caught as are people who learned of a material fact or change from any of these people (See subsection (c)). Perhaps the broadest part of the definition is subsection (e) in which anyone who learns of a material fact or change from anyone described in the definition as a whole and should have known that the person was in a special relationship with the issuer. This obligation is based on a reasonableness standard but nevertheless potentially implicates those who learn of the information not simply those who convey it.

Also important in understanding the term "special relationship" is the definition of "insider": Section 1(1) of the Ontario Securities Act, which mirrors legislation in other provinces (ASA, s. 1(aa); BCSA, s. 1(1); QSA, s. 89; NfldSA, s. 2(1)(s)) states:

s.1(1) "insider" or "insider of a reporting issuer" means,

(a) every director or senior officer of a reporting issuer,

(b) every director or senior officer of a company that is itself an insider or subsidiary of a reporting issuer,

(c) any person or company who beneficially owns, directly or indirectly, voting securities of a reporting issuer or who exercises control or direction over voting securities of a reporting issuer or a combination of both carrying more than 10 per cent of the voting rights attached to all voting securities of the reporting issuer for the time being outstanding other than voting securities held by the person or company as underwriter in the course of a distribution, and

(d) a reporting issuer where it has purchased, redeemed or otherwise acquired any of its securities, for so long as it holds any of its securities...

\section{(ii) Knowledge of a Material Fact or Change}

The knowledge on which the individual purchased or sold securities must meet the materiality standard contained in the definitions of these terms in the relevant legislation. If the information passed between individuals does not meet the materiality threshold, no claim of illegal insider trading can be made.

A "material fact" is defined as any "fact that significantly affects, or would reasonably be expected to have a significant effect on, the market price or value of the securities" (ASA, s. 1(gg); NSSA, s. 2(1); SSA, s. 2(1)(z); NfldSA, s. 2(1)(x); PEISA, s. 1(n)). A "material change" is "a change in the business, operations or capital of the issuer that would reasonably be expected to have a significant effect on the market price or value of any of the securities of the issuer..."54

54 Ontario, British Columbia, Alberta, Saskatchewan, Newfoundland, New Brunswick and Prince Edward Island all share this definition of material change. See discussion is chapter 6 above 


\section{(iii) Not Generally Disclosed}

The legislation does not define this phrase, but a 1976 Ontario Securities Commission (OSC) decision suggests that two factors must be examined when determining whether information has been generally disclosed. In Harold P. Connor [1976] OSCB 149, the OSC stipulated that the information must be "disseminated to the trading public" and the public must then be given a sufficient amount of time to "digest such information given its nature and complexity." In this case, the OSC suggested that one full trading day following the release of the information should pass before insiders trade. These two factors are embodied in National Policy 52-201 which states:

(2) Securities legislation does not define the term "generally disclosed". Insider trading court decisions state that information has been generally disclosed if:

(a) the information has been disseminated in a manner calculated to effectively reach the marketplace; and

(b) public investors have been given a reasonable amount of time to analyze the information.

In short, the term "generally disclosed" requires one to assess whether information has been released to the public and whether enough time has passed so that investors can analyze it.

\section{B. Tipping}

The second aspect of illegal insider trading is referred to as "tipping". This term does not appear in the statutory prohibition against the activity. The relevant statutory provision reads as follows:

No reporting issuer and no person or company in a special relationship with a reporting issuer shall inform, other than in the necessary course of business, another person or company of a material fact or material change with respect to the reporting issuer before the material fact or material change has been generally disclosed. (OSA, ss. 76 (2), (3); ASA , ss. 147(3), (4); BCSA, s.. 86(2), (3); NfldSA, s. 77(2); and QSA, s. 188).

Thus, tipping occurs if $x$ is in a special relationship with an issuer and reveals a material fact or a material change to $y$, other than in the necessary course of business, before such information has been disclosed to the public. In this example, $x$ is commonly referred to as the "tipper" and $y$ is the "tippee". To be sure, there are three basic elements of the insider trading offence for tipping. These are:

(1) the tipper must be in a special relationship with the reporting issuer;

(2) the tipper informs the tippee of a material fact or material change other than in the necessary course of business; and

(3) the information has not been generally disclosed. 
As the definition of special relationship suggests (OSA, s. 76(5)(e); ASA, s. 9; BCSA, s. 3; QSA, s. 189; NfldSA, s. 77(5) in the above example), the tippee also must know or ought reasonably to know that the tipper is in a special relationship with a reporting issuer. This requirement provides the tipper with a defence not available to others in a special relationship. It is important to note also that a tippee can also be a tipper if she, like the original tipper, is also in a special relationship with the issuer and passes material undisclosed information along to another person. If this other person also classifies as a tipper and passes information on to yet another person, it is easy to see how a chain of tippers can be formed. As the chain becomes longer, it becomes more and more difficult to isolate and detect insider trading.

\section{U.S. Federal Insider Trading Law}

\section{Rule 10b-5 -- Employment of Manipulative and Deceptive Devices}

It shall be unlawful for any person, directly or indirectly, by the use of any means or instrumentality of interstate commerce, or of the mails or of any facility of any national securities exchange,

a. To employ any device, scheme, or artifice to defraud,

b. To make any untrue statement of a material fact or to omit to state a material fact necessary in order to make the statements made, in the light of the circumstances under which they were made, not misleading, or

c. To engage in any act, practice, or course of business which operates or would operate as a fraud or deceit upon any person,

in connection with the purchase or sale of any security.

\section{Section 16(b) - Profits from purchase and sale of security within six months}

For the purpose of preventing the unfair use of information which may have been obtained by such beneficial owner, director, or officer by reason of his relationship to the issuer, any profit realized by him from any purchase and sale, or any sale and purchase, of any equity security of such issuer (other than an exempted security) or a security-based swap agreement (as defined in section 206B of the Gramm-Leach-Bliley Act) involving any such equity security within any period of less than six months, unless such security or security- based swap agreement was acquired in good faith in connection with a debt previously contracted, shall inure to and be recoverable by the issuer, irrespective of any intention on the part of such beneficial owner, director, or officer in entering into such transaction of holding the security or security-based swap agreement purchased or of not repurchasing the security or security-based swap agreement sold for a period exceeding six months. Suit to recover such profit may be instituted at law or in equity in any court of competent jurisdiction by the issuer, or by the owner of any security of the issuer in the name and in behalf of the issuer if the issuer shall fail or refuse to bring such suit within sixty days after request or shall fail diligently to prosecute the same thereafter; but no 
such suit shall be brought more than two years after the date such profit was realized. This subsection shall not be construed to cover any transaction where such beneficial owner was not such both at the time of the purchase and sale, or the sale and purchase, of the security or security based swap agreement (as defined in section 206B of the Gramm-Leach Bliley Act) involved, or any transaction or transactions which the Commission by rules and regulations may exempt as not comprehended within the purpose of this subsection. 


\section{Appendix 2}

\section{Econometric Estimation of Firm-Specific Stock Return Volatility}

To estimate firm-specific stock return volatility, we estimated the "market model" ordinary least squares (OLS) regression of the firm's monthly returns on the monthly returns to the market index:

$$
r_{i, t}=\alpha_{i, t}+\beta_{i} r_{m, t}+\varepsilon_{i, t},
$$

where $r_{i t}$ is the total return on stock $\mathrm{i}$ in period $t, r_{m t}$ is the total return on the market index over the same period, $t$, the $\alpha$ 's and the $\beta$ 's are the estimated OLS regression coefficients, and $\varepsilon_{i t}$ is the "unexplained"/unique/firm-specific component of stock $i$ 's return in period $t$. We estimate the market model using monthly returns, which we calculate from closing monthly stock prices (adjusted for dividends and stock splits) from January 2002 through December 31, 2005. We use Standard and Poor's Composite TSX Composite Index as the market index. The adjusted $\mathrm{R}^{2}$ from this regression measures the fraction of the variation in a firm's monthly returns that is explainable by changes in the market return. ${ }^{55}$ The remainder, i.e., the unexplained fraction of the variation in a firm's monthly returns, can be attributed to unique information about the firm (see, e.g., Roll, 1988; Durnev et al., 2003). Thus, 1- adjusted $\mathrm{R}^{2}$ is a proxy for firm-specific volatility. This is our second and theoretically more meaningful measure of stock return volatility.

$55 \quad \mathrm{R}^{2}$ is adjusted for degrees of freedom (see Roll, 1988). 